Pamiętnik Literacki 2012, 2, s. 59-100
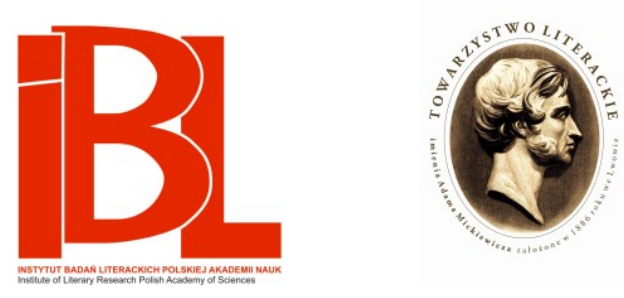

\title{
Poezja Julii Hartwig wobec egzystencji i metafizyki
}

Marta Flakowicz-Szczyrba 


\section{POEZJA JULII HARTWIG WOBEC EGZYSTENCJI I METAFIZYKI}

W roku 1973 Jerzy Kwiatkowski napisał o poezji Julii Hartwig słowa, które będą w latach następnych wielokrotnie przywoływane:

Przemianę, jaka dokonała się w tej poezji, określić można najkrócej jako jej przenicowanie się: z zewnątrz - do wewnątrz. Z jawy - w sen. Z jasności - w ciemność. Z Normy Dnia - w Pasję Nocy ${ }^{1}$.

Zauważając zmianę dykcji poetyckiej, autor Magii poezji odróżnia debiutancki tom Hartwig - Pożegnania (1956), z właściwą mu jasnością wizji i kulturową tematyką - od dwóch kolejnych (Wolne ręce, 1969; Dwoistość, 1971), w których interpretacji za kluczowe badacz uznaje oniryczność obrazu oraz zwrot ku zagadnieniom ostatecznym ${ }^{2}$. Jakkolwiek Kwiatkowski, z przyczyn oczywistych, nie miał

1 J. K w i a t k o w s k i, Felieton poetycki. „Twórczość” 1973, nr 9, s. 124.

2 Już jednak w debiutanckich Pożegnaniach (Warszawa 1956; dalej tomik ten oznaczam skrótem P oraz numerem stronicy) można by wskazać fragmenty, które niejako antycypują nowe jakości w tej poezji. W utworze Odwiedziny przywołany zostaje Józef Czechowicz - postać kształtująca w okresie międzywojennym literacki obraz Lublina, pod której wrażeniem pozostawała także młoda Julia Hartwig.

Jest $\mathrm{u}$ tego poety strof parę, które dorastającym podały obraz świata jak liść młody, jak zwierzę jeszcze gorące od narodzin, pełne przeczuć matki i niedrapieżne. [P 10-11]

- pisze zatem autorka, zaznaczając, że wiersze Czechowicza miały moc oddziaływania na młode umysły, zaszczepiania im jego sposobu postrzegania świata, a była to przecież optyka katastroficzna, obleczona w symbolikę snu. To doświadczenie, choć może nie kluczowe dla wyobraźni poetyckiej Hartwig, należy potraktować jako symboliczne i uwypuklające te aspekty jej poetyki, które dotąd zostały słabo wyeksponowane. Wpływ autora nuty człowieczej na początkujących twórców z tamtego okresu był ogromny, przejawiał się chociażby w podejmowanych przez nich próbach pisania „,pod Czechowicza”, o czym wspomina sama Hartwig, która również nie uniknęła owej fascynacji. Swoją przygodę z jego wierszami tak oto przedstawia: „Zetknięcie z Czechowiczem było początkowo dość powierzchowne, dopiero potem dojrzałam do jego poezji. W tym wtajemniczeniu w poezję Czechowicza dużą rolę odegrał Jerzy Pleśniarowicz, nieco starszy ode mnie kolega, młody poeta, zafascynowany twórczością Czechowicza" (J. H a rtw i g, Świat trzeba przefiltrować przez siebie. W: P. S z e w c, Wolność i współczucie. Rozmowy z pisarzami. Kraków 2002, s. 42), a w innym wywiadzie przyznaje: „Moja fascynacja poezją Czechowicza trwa do dzisiaj”; „Przyciąga mnie melodia, nastrój, intymność tej poezji, zwłaszcza jego wiersze poświęcone matce są niezwykle piękne” (Tam gdzie mogę ścigam morze. Z poetką J. Hartwig - rozmawia W. K a s s. „Topos” 2004, nr $3 / 4$, s. 11, 27). 
w 1973 r. wglądu w dalszą twórczość poetki, dostrzegł znaczącą dwubiegunowość tonacji ${ }^{3}$, która będzie odtąd towarzyszyć autorce Czułości. Ten właśnie zwrot zapoczątkuje w poezji Hartwig również ciemną nutę o proweniencji katastroficznej ${ }^{4}$, wieszczącą kryzysowy charakter świata i życia ludzkiego, a nierozerwalnie związaną także z rosnącą rolą podświadomości i symboliki sennej ${ }^{5}$. Owo pesymistyczne rozpoznanie bytu, jako istotny element modernistycznej świadomości, prowadzi Hartwig do pytań o miejsce człowieka na ziemi i próby określenia jego sytuacji egzystencjalnej. Kwiatkowski wieńczy refleksję nad trzema tomami wierszy słowami: ,To zaś, co [...] [w tej poezji] najważniejsze, to wielka powaga spraw ostatecznych, ukazanych jak gdyby z perspektywy tego momentu, kiedy »sny ostatnie przechodzą przez włosy «" - przeczuwając tym samym kierunek, w którym ta poezja podąży, a który będzie istotniejszy niż oniryczne konwencje ${ }^{6}$.

Symbolem zwrotu ku „Pasji Nocy” staje się Czarne Słońce, będące znakiem metafizycznego lęku, niepokoju oraz ciemnej ,podszewki bytu”. We wczesnym utworze Jeśli (z tomu Czuwanie, 1978), który można interpretować jako autocharakterystykę sytuacji podmiotu lirycznego, czytamy:

Jeśli będziemy patrzeć aż do bólu, może staną się ciałem ci, którzy krążą wokół bezustannie.

Jeśli śpiąc będziemy czuwać, by nie zboczyć z drogi, może noc dopuści nas do swoich najtajniejszych treści.

Tęsknimy do nich, opędzając się od natrętnych cieni dnia, które kładą się z nami do łóżka i towarzyszą nam, obstając przy swoim głupstwie.

Tą granicą między ułomnym dniem a nie doczytaną nocą posuwam się na wygnańczym wózku pod jasnym słońcem na niebie, z ciemnym słońcem pod powieką, ani tu, ani tam naprawdę nieprzynależną. [Jeśli, C $\left.33^{7}\right]$

3 Opozycje: jawa-sen, jasność-ciemność, wyznaczone przez Kw i t kow ski e go (op. cit.), przede wszystkim dotykają kwestii poetyki wierszy autorki Czułości. Dostrzegam możliwość wielowarstwowego odczytania oraz wyróżnienia kilku interpretacyjnych zrębów problemowych w dziele Hartwig. M. Te 1 i c k i (Poetycka antropologia Julii Hartwig. Poznań 2009, s. 11) chciałby widzieć trzy okresy twórczości poetki (1945-1978, 1980-2002, 1999-2007), odpowiadające triadycznemu ujęciu zagadnień służących jako klucze do zrozumienia wierszy z tych okresów. Owe klucze to pamięć, tożsamość i surrealizm. Wprawdzie pierwsze dwa z nich pozostaną istotne dla mojej refleksji, lecz nadałabym im inne proporcje w stosunku do problemów wskazywanych przeze mnie. Diachroniczne podejście do całości dzieła Hartwig wymaga bowiem według mnie wprowadzenia szerokich kategorii, które ogniskują w sobie szczegółowe zagadnienia. Tym samym jako fundamentalne dla poezji autorki Czułości traktuję kategorie egzystencji i metafizyki oraz refleksję metapoetycką.

4 Termin „katastrofizm” chciałabym tu pojmować szeroko jako „postawę światopoglądową wyrosłą z niepokojów i kryzysów duchowych współczesnego świata”, zgodnie z rozległą definicją przytaczaną przez J. K rys z a k a (Katastrofizm ocalajacy. Z problematyki poezji tzw. „Drugiej Awangardy". Poznań 1978, s. 5).

5 Jak zauważa G. R a v a s i (Apokalipsa. Przeł. K. S t o p a. Kielce 2002, s. 9): „Podstawa [...] systemów świętych symboli [tj. ujętych w Apokalipsie] ma charakter o n i r y c z n y, zgodnie ze stylem literatury apokaliptycznej, która lubiła odwoływać się do snów i widzeń".

6 Kwiat kow ski, op. cit., s. 125.

7 Skrótem C oznaczam tom J. H a r t w i g Czuwanie (Warszawa 1978). Poza tym, lokalizując przywoływane utwory tej poetki, stosuję następujące skróty: $\mathrm{B}=$ Błyski. Warszawa 2002; BP = Bez pożegnania. Warszawa 2004; $\mathrm{Ch}=$ Chwila postoju. Kraków 1980; Cz =Czułość. Kraków 1992; $\mathrm{D}=$ Dwoistość. Warszawa 1971; J = Jasne niejasne. Kraków 2009; N = Nie ma odpowiedzi. Warszawa 2001; O = Obcowanie. Warszawa 1987; T = To wróci. Warszawa 2007; W = Wolne ręce. Warszawa 1969; WA = Wiersze amerykańskie. Warszawa 2002; WW = Wybór wierszy. Warszawa 2000; Z = 
Podmiot wygnany, podmiot, któremu dane jest przeżycie graniczne - poeta. Cytowany poemat prozą przybliża nam jego znamienny rys świadomości. Jest to pewien rodzaj wtajemniczenia w złożoność egzystencji, bo ten, który widzi ciemną stronę słońca, ma wzrok profetyczny, sięgający w „,ciemności” dla zwykłych ludzi zakryte. Granica między ,ułomnym dniem a nie doczytaną nocą”, nasuwająca na myśl w pierwszej chwili wyodrębnienie dwóch sfer: jawy oraz snu, i przypisanych im praw poznania - rozciąga się wszak w głąb bytu, jako dział tego, co fizyczne i metafizyczne, naoczne i ,pod powieką” ukryte. Tę konstytutywną dla podmiotu sytuację egzystencjalnego wygnania można by łączyć z poczuciem wydziedziczenia czy wypędzenia, które Richard Sheppard określa jako centralne dla doświadczenia modernistycznego ${ }^{8}$. Utwór ten wprowadza ponadto dwa inne ważne wyznaczniki poetyckiego światopoglądu Hartwig - potrzebę przywoływania zmarłych (ich odczuwana ciągła obecność wskazuje na istnienie „drugiej strony”) oraz rolę podmiotowej „czujności” i zaangażowania wobec świata, która, ujęta niejednokrotnie w paradoksalnej formule (,jeśli śpiąc będziemy czuwać”, ,jeśli będziemy patrzeć aż do bólu’), wyraża dwoistość bytu.

Pomiędzy brzemieniem wygnania i nieprzynależności z jednej strony, a potrzebą zakorzenienia z drugiej oscyluje, pragnący restytucji sensu oraz metafizycznej podstawy bytu, podmiot wierszy Julii Hartwig, którego niespełnionym zamiarem stanie się dotarcie do istoty rzeczy i rozpoznanie prawd ostatecznych. Już w Pożegnaniach, w których liczne utwory wyrażają zagrożenie powojenne, widać tendencję do przeniesienia owego niepokoju na płaszczyznę egzystencjalną ${ }^{9}$. Dążenie to szczególnie uwypukli się we wczesnych tomach: Wolne ręce, Dwoistość, Czuwanie, Chwila postoju, w których maksymalizm poznawczy łączy się z profetycznym przeczuciem w ramach onirycznej konwencji ${ }^{10}$. W kolejnych zbiorach poetyckich (Obcowanie, Czułość, Zobaczone), wychodząc od rozpoznania krytycznego duchowości współczesnego człowieka, zmierza autorka Błysków ku trudnej obronie wiary w sens poszukiwania idei ładu i idei afirmacji rzeczywistości ponad świadomością tragizmu egzystencji oraz w sens ofiary ,spełnianej od stuleci" w perspektywie religijnej (Getsemane, J 28). Tom Nie ma odpowiedzi otwiera ostatni etap twórczości Hartwig ${ }^{11}$, w którym ze szczególnym nasileniem

Zobaczone. Kraków 2000. Liczby po skrótach wskazują numery stronic. Przywoływane cytaty biblijne pochodzą z: Pismo Święte Starego i Nowego Testamentu w przektadzie z języków oryginalnych. Oprac. Zespół Biblistów Polskich [...]. Biblia Tysiąclecia. Wyd. 2, zmien. Poznań 1980.

${ }^{8}$ R. S h e p pard, Problematyka modernizmu europejskiego. Przeł. P. Waw rzy s z ko. W zb.: Odkrywanie modernizmu. Przekłady i komentarze. Red. i wstęp R. N y c z. Wyd. 2. Kraków 2004, s. 112.

${ }^{9}$ Prócz wspomnianych już Odwiedzin zapowiedź owych katastroficznych przeczuć przynosi także inny utwór zamieszczony w debiutanckim tomie - Colloque sentimental (P 8), tak oto charakteryzowany przez Hartwig: „Ten poemat o ślepcach kończy się krzykiem, że budują dla nich obóz koncentracyjny - chciałam w nim wyrazić poczucie zagrożenia powojennego, które przenosi się jednak w inną sferę, i pokazać, że istnieją różne sposoby udręczenia człowieka" (Nie kłamać życiu. Julia Hartwig o ,Wierszach wybranych”, Arturze i dobrym życiu. Rozmawia J. S t r z ałk a. „Przekrój” 2010, nr z 13 X).

${ }^{10}$ Wymienione tu dominanty problemowe poszczególnych okresów twórczości Hartwig oczywiście nie wyczerpują się w nich, ale są kontynuowane, jedynie z innym rozłożeniem akcentów.

11 Wyróżniam zatem trzy etapy twórczości Hartwig, na które będę się powoływała w całości artykułu. Pierwszy obejmowałby okres 1956-1980 (od debiutanckiego tomu Pożegnania po Chwile postoju), drugi lata 1980-2000 (na ten czas przypada ukazanie się tomów: Obcowanie, Czułość oraz 
ujawnia się namysł nad momentem przejścia i nad niewyobrażalnym, wyrażający się w coraz krótszej frazie wiersza, w ascetycznej metaforze, w poetyce retorycznego pytania oraz w stopniowym wypieraniu obrazu poetyckiego przez rozważanie, osiągającym swoją kulminację w tomie Jasne niejasne ${ }^{12}$. W tych zbiorach ,niejasna" wizyjność ulega wyciszeniu, zaczyna natomiast dominować kontemplacyjna refleksyjność wychylona ku obrazom przeszłości, ale zawsze zanurzona w żywiole widzialnego konkretu. Całość omawianego dorobku Hartwig wiąże się więc z wyjątkową konsekwencją w podejmowaniu głównych pól refleksji nad egzystencją, także w perspektywie metafizyki, która - choć wskazywana subtelnie - okaże się nieodzowną płaszczyzną odniesienia, utwierdzającą byt.

\section{„Rozpacz się nie starzeje” - Hartwig wobec grozy istnienia}

Egzystencja w poezji Hartwig jest tylko pozornie jasna, w głębi okazuje się przesiąknięta metafizycznym lękiem i grozą życia. Autorka Czuwania za Karlem Jaspersem przyznaje jej dwoisty charakter, pisząc „o jasnej powierzchni rzeczy i zawartej w głębi ciemności" ${ }^{13}$. Wielokrotnie akcentuje niemożność przekazania „cichej wieści”, ukrytej w znakach świata, nie objawia się ona bowiem w zgiełku, nie rywalizuje o prymat w kakofonii codzienności. Lakoniczny poemat z wczesnego tomu Dwoistość kreśli relację, jaka kształtuje się między tym, kto dostąpił niemej, profetycznej ciszy, a barierą ludzkiego strachu przed jej posłyszeniem:

Zagłuszacie mnie krzykiem, śmiechem, dźwiękiem bitego szkła.

A jednak wołam ze zjeżonymi włosami i usta moje poruszają się jak usta przerażonej głuchoniemej, która podczas bankietu zobaczyła skrzydło nadlatującego pożaru. [Zagłuszacie mnie..., D 59]

Zobaczone), trzeci zaś rozpoczynałby się od tomu Nie ma odpowiedzi, a kończył się na ostatnim zbiorze opublikowanym do r. 2010, Jasne niejasne. G. K o c i u b a (Widzenia, sny, medytacje z morzem $w$ tle 〈o poezji Julii Hartwig〉. „Topos” 2004, nr 3/4, s. 44-48) wyznaczył w poezji autorki Zobaczonego dwa okresy: imaginatywno-epifaniczny oraz sensualno-medytacyjny, uzasadniając: „W pierwszym eksploracja świata i własnej podświadomości przybiera postać nadrealistycznych, onirycznych obrazów, zdradzających maksymalistyczne pragnienie dotknięcia bytu od wszystkich stron oraz zgłębienia zasady wszechrzeczy. W drugim widoczna jest większa koncentracja na zmysłowo dostępnych realiach, potrzeba dokładnego oglądu rzeczy, kontemplacja pejzażu, wreszcie medytacja nad ostatecznym sensem i przeznaczeniem naszego życia" (s. 44). Podział ten domaga się uszczegółowienia i wyodrębnienia z drugiego etapu twórczości Hartwig trzeciej fazy, która silnie zaznacza się od tomu Nie ma odpowiedzi poprzez zbiory Bez pożegnania, To wróci oraz Jasne niejasne. Zasadnicza różnica polega na pogłębionej refleksji metafizycznej i wychyleniu ku granicy przejścia, ale wpływa też na długość i brzmienie poetyckiej frazy oraz obrazowanie (poezja ta staje się mniej pejzażowa, a bardziej dyskursywna i rozbudowana narracyjnie). Jednocześnie epifania, która wszak zmienia swój charakter i ewoluuje, nie jest właściwa tylko pierwszemu okresowi wskazanemu przez Kociubę, ale stanowi istotowy wymiar także późnej poezji Hartwig.

${ }^{12} \mathrm{~W}$ rozmowie z J. K u r k i e w i c z e m (Julia Hartwig: Starość nie jest doklejona do życia wyspa. Rozmowa z J. Hartwig. Na stronie: http://wyborcza.p1/1,106967,8163295,Julia_Hartwig_Starosc_nie_jest_doklejona_do_zycia.html\#ixzz15LbRUXLW. Data dostępu 28 IV 2011) na temat tomu Jasne niejasne poetka przyznaje: „Odmienność tego tomiku od poprzednich widzę w przewadze refleksji nad obrazem, w upartym poszukiwaniu rozwiązań, nierzadko zakończonych poczuciem bezradności. Bo wiele jest odpowiedzi i w życiu, i w sztuce, które, choć mają pozór jasności, wcale nie są jasne".

${ }_{13}$ P. K u n c e w i c z, Julia Hartwig. W: Leksykon polskich pisarzy współczesnych. T. 1. Warszawa 1995, s. 316. 
Świat przez nas konstytuowany jest więc światem hałasu - hałasu, stworzonego, być może, tylko po to, by zagłuszyć złowieszczą ciszę, której synonimem staje się przerażona głuchoniema. Gradacja dźwięku, przybierającego postać wrzasku i odgłosu pękającego szkła oraz śmiechu podszytego grozą, stanowi zatem nie zobrazowanie pulsu i witalności życia, ale emanację lęku. „Jeśli kto ma uszy, niechaj posłyszy!” (Ap 13, 9) - czytamy w Objawieniu św. Jana; ,, a jednak wołam ze zjeżonymi włosami” - przyznaje podmiot, który niesie apokaliptyczną wieść, wbrew ogłuchłemu tłumowi. Jednak owo wezwanie nie przybiera już formy biblijnego nakazu, jest działaniem „pomimo” i „na przekór” światu, przedzieraniem się „do” świata z nieczytelnym przesłaniem niemych ust. Ten krótki poemat wprowadza atmosferę zagrożenia, której źródeł upatrywać można nie w odniesieniu do konkretnych sytuacji, lecz w strukturze bytu. Ujawnianie „ciemnej podszewki świata”, poprzez którą wyraża się nadchodzący kres, jest właściwe wielu utworom Hartwig, przeczucie końca nie odstępuje autorki Czułości, a „skrzydło nadlatującego pożaru” zagarnia coraz większą przestrzeń. Grozę tych wierszy buduje i wzmacnia zabarwienie profetyczne, osiągające swoją kulminację w Dwoistości, która utrzymana jest w ciemnej barwie przestrzeni onirycznej, przesiąkniętej znakami śmierci i końca. Liryki takie, jak To słowo (D 28), Cierpiacy pejzaż (D 60), Zejdź do gondoli (D 24), Mówity odchodząc (D 33), Pojedynek (D 47) ukazują niepokojącą stronę egzystencji, nawiązując do symboliki chrześcijańskiej (m.in. jeźdźców Apokalipsy, jelenia z krzyżem na czole), która potęguje atmosferę zbliżającej się katastrofy. Ciemna, złowieszcza i tajemnicza tonacja zdominowała nie tylko duchowość człowieka, transpozycja ludzkich odczuć następuje także na otoczenie:

Wyrwane z korzeniami ramię, które próbuje wrosnąć w ziemię, przywierając do niej z całą miłością.

Obłąkany dąb z gęstwiną wężów w koronie, który chce spokojnie trwać, nie skazany na profetyczność.

Obolała głowa słońca, które chyli się z wolna, by wysłuchać litanii skarg szeptanych wyschniętymi językami. [Cierpiacy pejzaż, D 60]

Pejzaż (na którego malarskość w tej poezji wskazywano wielokrotnie) to część natury oswojona ludzkim okiem, wpisana w rejony kultury. Małgorzata Baranowska nazwała Hartwig poetką krajobrazu ${ }^{14}$, ale wydaje się, że tylko w tym sensie, w jakim jest to krajobraz, który podlega pełnej liryzacji i antropomorfizacji. Żyje on zatem natchniony interpretującym spojrzeniem podmiotu, a w konsekwencji przybiera właściwy mu stan emocjonalny. Proste określenia zmieniają charakter scen: „wyrwane ramię”, „obłąkany dąb”, „obolała głowa słońca”, niosą skojarzenia męki i cierpienia w wymiarze religijnym. Specyfika poematu prozą pozwala na wykreowanie zliryzowanego obrazu, otwartego dzięki bogatej metaforyce. Ukazuje się on jako całość, nie statyczna jednak, gdyż Hartwig umiejętnie wprowadza ruch do każdego tekstu.

Wizyjny charakter rozpoznania zagrożonego bytu wkracza także w konkret codzienności, która zapełnia się postaciami naruszającymi zasady logiki i realizmu. To pośród ulic symboliczne rekiny „Krążą wokół ciebie, zawsze głodne” (Rekiny,

${ }^{14}$ M. B a r a n o w s k a, Julia Hartwig - podróż do wspólczesności. Na stronie: www.culture. p1/baza-literatura-pelna-tresc/-/eo_event_asset_publisher/eAN5/content/julia-hartwig-podroz-do-wspolczesnosci. Data dostępu 21 VI $200 \overline{7}$. 
Ch 59), a w ciele postaci ,dzwoni dzwonek na trwogę" (W jej kruchym ciele, W 46). Iwona Smolka pisze: „Poetka wie, że kataklizmy lubią się powtarzać. Groza nie mija. Jest przyczajona. Wie również, że groza, tak jak piękno, dobroć, ekstaza i strach, jest wpisana w istnienie" ${ }^{15}$. Nigdy nie znika więc poczucie dwoistości bytu, druga, niejasna, mroczna strona zawsze istnieje, tak w sferze snu, gdzie ,ciężary opadają na dno / i patrzą stamtąd uważnymi i szeroko otwartymi oczami” (Wahanie, N 70), jak i w obszarze codzienności, bo zgodnie ze słowami wiersza: „nieznany jest czas, kiedy smuga dymu / uniesie się z wystudzonego wulkanu” (W 28).

Szukając u Hartwig znaków świadomości katastroficznej, trzeba przesunąć punkt ciężkości z apokaliptycznych wizji końca na wnikliwą analizę socjologicznych, kulturowych i egzystencjalnych przejawów kryzysu. Istotny z perspektywy podjętych rozważań jest fakt, iż autorka Zobaczonego piętnuje tendencje relatywizujące, upatrując ich źródeł przede wszystkim w przemianach dzisiejszej duchowości, takich jak odejście od „prawd pierwszych”, zanik teleologii, załamanie się wiary i sensu, czy w osłabieniu metafizyki. To zaś w następstwie implikuje oznaki kryzysu w postaci określonych zachowań społecznych ${ }^{16}$. Symptomy niepokoju wdzierają się zatem w tę poezję wraz z troską o zasadnicze uniwersalia. Jak podkreślał Leszek Kołakowski w r. 1990:

nie jest [upowszechnienie słowa „kryzys”], być może, wynikiem naszego językowego niedbalstwa, ale zdradza mgliste poczucie, że wszystkie formy życia, organizacji społecznej, myślenia i odczuwania, wszystkie składniki naszej cywilizacji są dotknięte schorzeniem i że zarazem nikt nie zna na to schorzenie radykalnego lekarstwa; że niepewność co do losów ludzkości stała się powszechna ${ }^{17}$.

Dojmujące odczucie załamania współczesnej kultury, literatury, systemów wartości stało się doświadczeniem o charakterze totalnym, ponieważ nie ma zjawiska, które by zdołało ustrzec się krytyki. Autorka Czułości dostrzega ów pierwiastek negatywistyczny, wyrosły z dorobku późnomodernistycznej krytyki kultury oraz osłabienia metafizyki, sama nie dochodzi jednak nigdy do pełnej negacji. Elementy świadomości kryzysowej ${ }^{18}$ jako diagnoza kondycji współczesności

15 I. S molk a, Prawo do sprzeczności (Julia Hartwig). W: Dziewięć światów. Wspótczesne poetki polskie. Warszawa 1997, s. 21.

${ }_{16}$ Współodpowiedzialność i utrzymanie mocnych waloryzacji w aspekcie czynu, na to, co dobre i złe, powinny być według J. H a r t w i g (Mała szkodliwość społeczna. W: Pisane przy oknie. Warszawa 2004, s. 32) podstawą życia społecznego: „Jeśli spojrzeć z tej perspektywy na wszelkie zło, jakie się u nas pleni, można by zaryzykować twierdzenie, że zaczyna się ono zawsze od zdradliwego poczucia, że ma ono »małą szkodliwość społeczną《". Tę odnoszącą się do wyroków sądów i występków społecznych myśl, którą odnajdujemy w jednym z felietonów ze zbioru Pisane przy oknie, można potraktować jako egzemplifikację ogólnego nastawienia Hartwig wobec tendencji relatywizujących

${ }^{17}$ L. K oła k o w s k i, Cywilizacja na ławie oskarżonych. Warszawa 1990, s. 121.

${ }_{18}$ P. Śliw ińs ki w artykule Różewiczowska egzegeza zła (w: B. K a nie w s k a, A. Leg e ż y ń s k a, P. Ś li w iń s k i, Literatura polska XX wieku. Poznań 2005, s. 188) pisze: „W literaturze współczesnej można obserwować współistnienie dwóch odmiennych rodzajów świadomości: afirmatywnej i kryzysowej. Pierwsza przejawia się w dziełach budujących jasny, a przynajmniej względnie harmonijny obraz świata, w którym artysta odkrywa obecność wyższego sensu, fundowanego przez Boga, naturę czy też historię. Świadomość kryzysowa wyrasta z negatywnych doświadczeń cywilizacyjnych, odrzuca pociechę religii i oczekuje nieuchronnego Końca. [...] W każdym z tych światopoglądów inaczej rozkładają się wartości etyczne. Afirmacja świata oznacza zarazem wiarę w niezniszczalność dobra. Świadomość kryzysowa konstatuje przewagę zła". 
wyłaniają się w tej poezji, będąc niezbędnym rewersem afirmacyjnej postawy wobec rzeczywistości. Jeden z filarów światopoglądu poetyckiego Hartwig stanowi bowiem afirmacja, która wynika z potrzeby ponownego odnalezienia sensu i zakorzenienia, a nie z bezkrytycznej akceptacji zawartej w przekonaniu o Wielkim Łańcuchu Bytów i przyjmującej sens za oczywisty. Jest to zatem jakościowa różnica między świadomością nowoczesną a przednowoczesną.

Centralnym punktem refleksji czyni autorka Zobaczonego utratę życiowego sensu. Wpisuje się tym samym w najsilniejszy w literaturze przełomu XX i XXI w. nurt, który Anna Legeżyńska w Geście pożegnania określiła mianem nowej elegijności, akcentując zarazem jego nasycenie świadomością katastroficzną i tęsknotami metafizycznymi ${ }^{19}$. Jednocześnie badaczka potwierdziła, że: „Nostalgiczna tęsknota dzisiejszych elegijnych poetów ma za przedmiot nie tyle przemijające życie, ile zagrożony w tej epoce Sens" ${ }^{20}$.

Egzystencja pozbawiona kierunku i celowości, której odjęty został duchowy wymiar wędrówki, znamionuje kondycję współczesnego człowieka. Przywołani w poemacie prozą Myślimy metaforyczni pielgrzymi symbolizują bowiem życie jako zbliżanie się do Boga czy też idei transcendencji, życie, którego zamierzony bieg określony jest przez ponadludzki determinant, a sens może mieć podbudowę metafizyczną.

Myślimy, że nadejdzie chwila próby.

A tymczasem pielgrzymi, których wieźliśmy, od dawna spoczywają na dnie morza i są już nie do rozpoznania.

Myślimy: od jutra będziemy żyli naprawdę.

A przecież to już życie i niejeden z nas jest już martwy na dobre. [Ch 30]

Wiersz ukazuje podstawową rozbieżność porządków duchowego i egzystencjalnego, między którymi nie ma łączności. Hartwig, posługując się podmiotem zbiorowym, tworzy scenę o znaczeniu uniwersalnym, ogólnoludzkim i obnaża życie człowieka jako pasmo złudzeń, pozorów oraz utraty czujności i wewnętrznego słuchu. To ,życie na niby” jest rozmijaniem się z przypisanym każdemu egzystencjalnym czy religijnym zadaniem. Gdy podmiot poematu Hartwig mówi: „Myślimy: od jutra będziemy żyli naprawdę. / A przecież to już życie i niejeden $\mathrm{z}$ nas jest już martwy na dobre", to przecież w tych słowach pobrzmiewa ton Janowy z Listu do Kościoła w Sardes: „Znam twoje czyny: masz imię, [które mówi], że żyjesz, a jesteś umarły. Stań się czujnym i umocnij resztę, która miała umrzeć, bo nie znalazłem twoich czynów doskonałymi wobec mego Boga" (Ap 3, 1-2). Napomnienie i surowa przestroga z Objawienia św. Jana przybierają w utworze formę refleksji i gorzkiego stwierdzenia popartego świętym tekstem Biblii. Ludzkość jest tu zaklęta w swoim somnambulicznym tańcu, nie słyszy głosu wołającego Ojca, a Jego wysłannicy są „nie do rozpoznania”. Przeoczenie wezwania pociąga za sobą poczucie zmarnowanego, bezproduktywnego życia. Czyny człowieka nie mają bowiem wyższej sankcji, metafizycznego uzasadnienia. Będąc więc głuchym na chwilę próby, tym samym nie daje on sobie szansy na przemianę.

Zwątpienie, zanik wszelkiej teleologii, niemożność odnalezienia Sensu rze-

19 A. L e g e ż y ń s k a, Gest pożegnania. Szkice o poetyckiej świadomości elegijno-ironicznej. Poznań 1999, s. 9.

${ }^{20}$ Ibidem, s. 21. 
czywistości zamieniają życie jednostki w dramat rozpaczy i samotności. Dzieje się tak, co znamienne, głównie na płaszczyźnie indywidualnej, w tym wymiarze bowiem odczucie to odsłania największą grozę nicości, bez odniesień do doświadczenia wspólnotowego. Człowiek ze swoją pustką pozostaje sam, skoro, ogołocony z aksjomatów i autorytetów, w drodze upartej emancypacji rozumu pozbył się wszelkich wyższych instancji prawdy i Sensu. Kołakowski podaje, że Friedrich Nietzsche jako krytyk kultury nowoczesnej sformułował radykalną diagnozę:

świat nie wytwarza sensu i nie wytwarza także różnicy między dobrem i złem, rzeczywistość jest bezcelowa i nie ma za nią żadnej ukrytej rzeczywistości, świat, jakim go widzimy, jest Ultimum, nie próbuje nam niczego powiedzieć, nie odsyła do niczego innego, wyczerpuje się sam w sobie i jest głuchoniemy ${ }^{21}$.

W wierszu Oda do nicości z tomu Czułość autorka dokonuje podobnego rozpoznania kondycji współczesnego świata, wykorzystując dwojaką stylistykę. Posiłkując się liryką roli i trzecioosobową narracją, Hartwig rozpoczyna utwór od zdystansowanego i lakonicznego zarysowania sytuacji, co wzmacnia poczucie wyobcowania oraz osamotnienia anonimowej postaci przedstawionej w wierszu, która ukazuje swą małość i nieskuteczność starań zmierzających do zapełnienia duchowej pustki.

Ekspresyjną, obfitującą w wykrzyknienia i apostrofy tonację ody wprowadzają dopiero następujące dalej odwołania do uczuć, które przerastają człowieka (samotności, zwątpienia, rozpaczy), sprawując nad nim władzę. Uczucia te stają się postaciami tytułowej nicości:

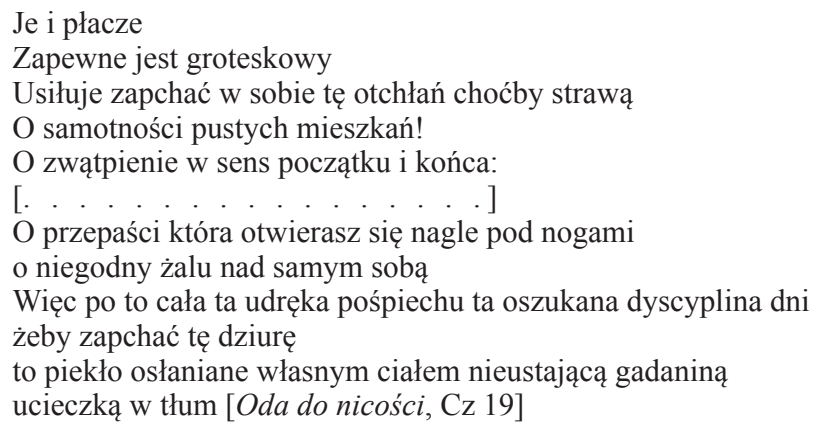

Hartwig formułuje ciemną i niepożądaną prawdę o naszym życiu. Mówiąc po sartre'owsku: piekło to nie przestrzeń kary i grzechu, ale to, co jest w nas samych, „osłaniane własnym ciałem [...]”. Stajemy się więc konstruktorami owego locus horridus, tak jak staliśmy się unicestwicielami sensu. W świecie ponowoczesnym zbiorowość straciła zdolność kreowania doświadczania wspólnotowego, a sensotwórczy charakter publicznych agor zanikł ${ }^{22}$. W Odzie do nicości w miejsce wspól-

${ }^{21}$ K oła kow s ki, op. cit., s. 205.

${ }^{22}$ Zob. Z. B a u m a n, Globalizacja. I co z tego dla ludzi wynika. Przeł. E. K 1 e k o t. Warszawa 2004. O potrzebie wypracowania nowego języka wspólnotowego i kryzysie wspólnotowości w etyce ponowoczesnej pisze także A. B i elik-R ob s on (Czy istnieje etyka ponowoczesna? O prymacie różnicy we współczesnej refleksji moralnej. W: Inna nowoczesność. Pytania o współczesna formułe duchowości. Kraków 2000, s. 226): „Język różnicy, nie kontrowany żadnym równie silnym językiem tożsamości, dokonuje pełnego i wciąż postępującego rozbioru kolejnych całości. 
noty pojawia się tłum, który przywodzi na myśl Gassetowską masę. Kryzys duchowości staje się zarazem tryumfem samotności. Metaforyczna, wewnętrzna „otchłań”, „przepaść”, „dziura” otwiera się przed człowiekiem jako rezultat mierzenia się z samym sobą, jest zatem przepaścią w najwyższym stopniu prywatną. Nicość przybiera różne imiona, a wszelkie działania jawią się jako niezborna, chaotyczna ucieczka i poszukiwanie paliatywu na ból pustki, na egzystencjalne przerażenie. Samotni pozostajemy więc i wewnętrznie, i w tłumie.

W zakończeniu wiersza, na co wskazywał także Marian Stala, „Pojawia się za to przeżycie znacznie bardziej podstawowe, egzystencjalne i metafizyczne zarazem. Jest nim widzenie własnej cielesności, ciała współtworzącego ludzką osobę, jako osłony przed nicością" ${ }^{23}$. Interpretując utwór w kontekście odwołań do ody, która w tradycyjnej odmianie jest przecież dziełem pochwalnym, odczytujemy go jako przesiąknięty ciemnym, podszytym rozpaczą i zabarwionym ironią patosem wobec przekraczającej nas pustki.

Hartwig, świadoma egzystencjalnego dramatu człowieka, dotkliwie odczuwa kryzys w. XX, nigdy jednak nie wybiera poetyckiej drogi konstatacji zła. Pisząc o owym kryzysie, czyni to językiem przejrzystym, wierna szerokiej frazie wiersza. W tym sensie można mówić o zbliżeniu do ducha klasycyzmu, poprzez odwołanie się do ideału dystansu oraz intelektualizacji nawet najmroczniejszych doznań. Krystyna Rodowska tak ocenia poetykę Hartwig: ,jasność i prostota jej dykcji poetyckiej, przez które przebija »jądro ciemności«, jest w moich oczach lekcją umiaru nie do podrobienia, umiaru, który nazwałabym »heroicznym «"24.

Wykorzystując topos Nicości, który, jak twierdzi Legeżyńska, jest kluczowy dla współczesnej elegijnej świadomości poetyckiej ${ }^{25}$, Hartwig rozważa kryzys duchowości. Tym samym $\mathrm{w}$ jej tekstach odbija się jedno z najistotniejszych doświadczeń modernistycznej formacji - doświadczenie nihilizmu, polegające „na osuwaniu się metafizycznego gruntu, na którym zbudowana została kultura Zachodu” ${ }^{26}$. Ten swoisty brak „podstawy” wyznacza zatem paradygmat, wobec którego określa się obecnie człowiek, także autorka Czułości. Będzie mu odtąd towarzyszyło poczucie opuszczenia, pozbawienie opiekuńczej ręki Opatrzności i egzystencjalna bezdomność, prowadząca do ciągłego poszukiwania śladów całości i jedności ze światem.

Źródeł egzystencjalnego dyskomfortu, przypisywanego nowoczesności, upatruje się już w kartezjańskiej emancypacji rozumu i w zanegowaniu celowego porządku przyrody, a co za tym idzie - w stopniowym pozbawieniu świata duszy ${ }^{27}$.

Następujące po sobie głośne ponowoczesne »śmierci« - człowieka w ogóle, wspólnoty, społeczeństwa, a nawet pojedynczego podmiotu - są ofiarami różnicy, jakie późna nowoczesność godzi się ponieść, byle tylko nie popaść w stare błędy języków wspólnotowych".

${ }^{23}$ M. S t a 1 a, Nicość. O jednym wierszu Julii Hartwig. W: Druga strona. Notatki o poezji wspótczesnej. Kraków 1997, s. 82. Autor przeprowadził wnikliwą interpretację Ody do nicości odkrywając trzy perspektywy mówienia w utworze, które składają się na jego bogatą semantyczną całość: skarżącej się duszyczki, ironisty-moralisty oraz ,głosu mądrego i pesymistycznego [...] doświadczenia" (s. 81).

${ }^{24}$ K. R o d o w s k a, Lekcja umiaru heroicznego. „Kwartalnik Artystyczny. Kujawy i Pomorze” 2005 , nr 2, s. 82.

${ }_{25}$ A. L e g e ż y ń s k a, Krytyk jako domokrążca. Lekcje literatury z lat 90. Poznań 2002, s. 15.

26 A. S k r e n d o, Poezja modernizmu. Interpretacje. Kraków 2005, s. 14.

27 Zob. Kołakowski, op. cit., s. 205. 
Przewrót oświeceniowy przyniósł w konsekwencji „odczarowanie świata” ${ }^{28}$, wyzuł go z pierwiastka irracjonalnego i mitycznego dzięki wiedzy. Do restytucji Tajemnicy, do ponownego zaczarowania będzie nawoływać Hartwig, widząc w złudzie idei wszechwładnego rozumu oraz w kulcie indywidualizacji, nie wspartym na horyzoncie tradycji ${ }^{29}$, niektóre źródła kryzysu współczesności. Duchowa kondycja człowieka, którego rzeczywistość przypomina Weberowski świat po odczarowaniu (Entzauberung) ${ }^{30}$, pozbawiony Tajemnicy i zdziwienia, pozostanie stałym tematem refleksji poetki aż do najnowszego tomu Jasne niejasne, w którym czytamy:

Jesteśmy w krainie czarów

Ale czar został odjęty

[......... . . $]$

Madame Salmajour która nauczyła się wróżyć w Oceanii

przepowiada powszechną alergię na prawdy pierwsze

i twierdzi że do tradycji zaglądamy już tylko

jak do przechowalni starzyzny

Być może jednak myli się wróżąc że zapanuje teraz

pozbawiona rytuału Religia Czarnych Dziur

skoro nawet z szerzącą się dziś mieszanką wiar

są kłopoty I jeśli nawet Budda i Chrystus

mogą żyć w zgodzie

choć nie godzą się ze sobą ich święte przypowieści [Gdzie jesteśmy, J 7]

Owo „Gdzie jesteśmy” oznacza bycie w świecie, próbę egzystencjalnego zakorzenienia i identyfikacji. ,To pytanie o punkt widzenia. Wybór właściwego miejsca obserwacji, z którego widzę świat i widzę siebie samego, ma konsekwencje ontologiczne, epistemologiczne, estetyczne. »Ja« należy do krainy czarów, z której czar został zdjęty" 31 . Hartwig nie neguje więc stanu ,pierwotnego zaczarowania”, jej poetycka refleksja znajduje oddźwięk w słowach Agaty Bielik-Robson:

Świat odczarowany, wyobcowany, zmienny i ulotny, świat budzący lęk i niepewność w swych mieszkańcach, którzy z nostalgią wspominają utracony sens „dawnych mitologii”-

${ }_{28}^{28}$ M. Horkheimer, Th. W. A d o r n o, Dialektyka oświecenia. Fragmenty filozoficzne. Przeł. M. Łu k a si e w i c z. Przekład przejrzał i posłowiem opatrzył M. J. S i e m e k. Warszawa 1994, s. 19.

${ }^{29}$ W Etyce autentyczności Ch. Ta y lor (Przeł. A. P a w e le c. Kraków 1996), zajmując się tzw. trzema bolączkami nowoczesności, uznał za główną z nich ,źle” pojęty indywidualizm. Zdyskredytowanie wszelkich hierarchii społecznych czy też kosmicznych, które nadawały sens światu, doprowadziło do jego odczarowania. Autor doszedł do wniosku, że utrata celu w życiu wynika z zawężenia perspektywy moralnej i jest kosztem nadmiernego skupienia się na sobie. Taką postawę określił „źle” pojętym indywidualizmem, który czyni nasze życie mniej znaczącym i mniej związanym z innymi ludźmi. ,Wielokrotnie dawano wyraz obawie, że wraz z utratą szerszych horyzontów działania - społecznych i kosmicznych - jednostka utraciła coś ważnego. Niektórzy mówili w tym kontekście o zaniku heroicznego wymiaru życia. Ludzie utracili poczucie wyższego celu: czegoś, za co warto umierać" (T a y 1 o r, op. cit., s. 11). Autor Etyki autentyczności uznaje za głęboką pomyłkę kult tzw. indywidualizmu samorealizacji, która sprowadza się do swoistego relatywizmu, zakładającego, że każdy ma prawo do własnych wartości i własnego sposobu życia bez odniesienia do horyzontu rzeczy istotnych.

${ }^{30}$ M. We b e r, „Asceza i duch kapitalizmu”. W: Szkice z socjologii religii. Przeł. J. P r o k opi uk, H. Wand ow s ki. Warszawa 1995.

${ }_{31}$ J. Ł u k a s i e w i c z, , Być blisko na odległość”. „Kwartalnik Artystyczny. Kujawy i Pomorze" 2009, nr 2, s. 123. 
tylko „czeka na dotknięcie miłości”, by stać się na powrót, tak jak chciał tego Novalis, domem człowieka nowoczesnego ${ }^{32}$.

Człowiek nowoczesny w liryce Hartwig zatracił podstawowe zmysły odbioru rzeczywistości - słuch, wzrok, czucie, co więcej, zatracił zdolność odczytywania znaków i życia w przestrzeni mitycznej:

\section{ki. $[\ldots]$}

Zbiorowe drogi ludzkich mitów opuszczone dla szczypania przydrożnej traw-

Tęsknota do symboliki trwałej. Nie przez szpary, dziury w płotach i piwnice. Wejść głównymi drzwiami, gdzie umarli czekają na żywych w nie cierpiących zwłoki sprawach. Gdzie żywi staną się na powrót żywymi. [Co mu ślina na język przyniesie..., Ch 27]

Z zanikiem sensu wiązać się będzie również kryzys wiary, która go konstytuowała. „Alergia na prawdy pierwsze” i „Religia Czarnych Dziur” to kontynuacja gorzkiej refleksji, utwierdzającej w przekonaniu, że niedostępna nam jest świeżość i autentyczność religijnego przeżycia pierwszych chrześcijan, że „Odjęty nam został niepokój oczekiwania”. Na zasadzie opozycji powołuje się Hartwig na mit początków w kontekście historii biblijnych, by wskazać regresyjny charakter współczesnej duchowości.

Odjęty nam został niepokój oczekiwania

trochę soli na język garstka wody w chrzcielnicy

i oto jesteśmy $w$ gronie wybranych

Co raz dane - przyjęliśmy i komu osądzać czyśmy letni w wierze

czy tak już w niej zadomowieni jak małżonkowie żyjący pod jednym dachem

od dziesiątków lat i nie skłonni do zadziwień

[. . . . . . . . . . . . . . . . . . ]

O początku obdarowany łaską dotknięcia

nie skażony bezwolnością i łatwym dziedziczeniem [Nad „Dziejami Apostolskimi”, Z 68]

„Łaska dotknięcia”, czyli bezpośrednie objawienie się Boga w historycznej rzeczywistości, namacalne zetknięcie się dwóch przestrzeni: materialnej i Boskiej, jest darem niedostępnym dzisiejszemu człowiekowi. Poczucie wygnania, będące skutkiem erozji wyobraźni religijnej, wiedzie więc do utraty spójności ,sfer materialnej, ludzkiej i metafizycznej" 33 .

Pesymistyczna diagnoza duchowości jednostki i jej zagubienie w świecie prowadzą Hartwig do pytania o istotę owego niedostatku natury ludzkiej w wymiarze ponadhistorycznym ${ }^{34} \mathrm{i}$ ponadspołecznym. Autorka Czułości podejmuje trud rozpoznania zła, które w jej poezji występuje zawsze w perspektywie antropocentrycznej. Zdaniem Józefa Tischnera, dramat dobra i zła jest problemem metafizycznym, następnie wzbogaca się o wymiar etyczny bądź religijny ${ }^{35}$. Podmiotem

32 A. B i e li k - R o b s o n, Duch powierzchni. Rewizja romantyczna i filozofia. Kraków 2004, s. 99.

33 S he p pard, op. cit., s. 112.

${ }^{34}$ Zło w perspektywie historycznej nie leży w centrum naszych zainteresowań, trzeba jednak nadmienić, iż Hartwig nie omija tego tematu; dość przywołać utwory takie, jak: Wjądrze ciemności, Siedziały panie, a w szczególności wiersze Rozłaczenie, Victoria, Koleżanki, $W$ drodze z tomu Bez pożegnania (s. 5, 7, 20-21), w których odbija się doświadczenie okrucieństwa wojny i okupacji.

${ }_{35}$ Zob. T. G a d a c z, Problem zła w filozofii Józefa Tischnera. „Horyzonty Wychowania” nr 7 (2005), s. 22. 
działań, w których przejawia się zło, okazuje się wyłącznie człowiek, ponieważ tylko on jest w stanie wypowiedzieć metafizykę dobra i zła ${ }^{36}$.

Pierwiastek zła w istocie ludzkiej znajduje swoje umocowanie już w zreinterpretowanej przypowieści o początku, jaką jest wiersz Powrót z tomu Czułość. Tu dezintegracja rzeczywistości (zewnętrza) następuje jako proces wtórny wobec rozpadu duchowego wnętrza. Dramat ludzkiego życia spełnia się więc poprzez burzenie Boskiego porządku ${ }^{37}$.

Bóg tworzył w ciszy.

Żeby słychać było szum traw i wizg jaskółki.

Tworzył w ciszy i skupieniu.

[. . . . . . . . . . . ]

A my napełniliśmy świat zgiełkiem pustych słów, hukiem i wrzawą [1. Niedorośli, Cz 93]

Pan Bóg przegonił chaos ze wszechświata. Ustalił rodzaje, podzielił gatunki.

Wówczas chaos schronił się w naszym wnętrzu.

I powoli wylewał się z niego, zagarniając świat na nowo. [2. Powrót, Cz 93]

Paul Ricoeur wyróżnił cztery odmiany mitycznych opowieści o genezie i końcu zła, wśród nich mit obrazujący dramat stworzenia jako walki boga z chaosem, co implikuje „tożsamość zła i »chaosu« oraz zbawienia i »stworzenia«"38. Bóg poprzez uporządkowanie chaosu - kreacyjny akt nadania rzeczom kształtu - zwalczył zło, przypisał światu jego role i funkcje, określił cele i kategorie, budując tym samym podstawę bytu. Zło, jako pierwiastek rozpadu, znajduje jednak swoje miejsce w ludzkim wnętrzu. Jak pisze Ricoeur w Symbolice zła: „każdy wymiar człowieka nosi podwójne, nałożone na siebie znamię: przeznaczenia do dobra i skłonności do zła" ${ }^{39}$. Tytułowy Powrót nie jest więc zmierzaniem do pierwotnego, Boskiego ładu, ale jego przeciwieństwem, postępującym regresem, zwrotem w kierunku chaosu i nieokreśloności. Świat zyskuje więc charakter entropiczny z winy jednostki, której wybory stają się źródłem zamętu, braku jasności i Boskiego uporządkowania. Bóg przedstawiany jest w wierszach Hartwig jako instancja wyższego, nadludzkiego, metafizycznego porządku, Jego pojawienie się w wierszu nie musi wszak wyrażać od razu deklaracji religijnej, funkcjonując często jako pewna forma uogólnienia i symboliki kulturowej.

Poprzez odwołanie do statusu „wnętrza” człowieka Powrót sytuować należy w jednej linii interpretacyjnej z utworem Natura twoja... z tomu Obcowanie. Skaza zła, zwątpienie w pierwotne dobro człowieka jako uwarunkowanie jego istoty stanowią oś myślową obu tekstów. Ten dualizm natury to wyłącznie ludzka własność:

Natura twoja jest zła Z tym się pogódź

Woła przez ciebie głosem który cię przeraża

Słowami których zdawało ci się - nie miałeś w sobie

Wytryska z ciebie inna niźli o niej mniemasz

${ }^{36}$ Zob. J. Ti s c h n e r, Zarys filozofii człowieka dla duszpasterzy i artystów. Kraków 1991, s. 98.

37 Zob. J. D r z e w u c k i, Patrz przed siebie. W: Smaki stowa. Szkice o poezji. Wrocław 1999, s. 154 .

${ }^{38}$ P. R i c o e u r, Symbolika zła. Przeł. S. C i c h o w i c z, M. O c h a b. Warszawa 1986, s. 163.

39 Ibidem, s. 232. 
jak wrzące źródło o zapachu siarki

pod którym omdlewają zielone łąki pozoru [Natura twoja..., O 26]

Zło ukonstytuowane jest więc we wnętrzu człowieka, skąd wyziera niczym apokaliptyczne „źródło o zapachu siarki”. To „ciemne źródło”, jak by powiedział Andrzej Franaszek, napawa przerażeniem. Podległy owej naturze człowiek ze strachem odkrywa, iż działa pod jej wpływem wbrew własnym złudzeniom. Demon chaosu ukazuje się w poezji Hartwig wielorako: przede wszystkim w sposobie wyrażania, w języku, który niczym nie przypomina już mowy Początków (Mowo, Mowo, Ch 20; Co mu ślina na język przyniesie..., Ch 27; Gdzie jest, gdzie sq, Cz 21), $\mathrm{w}$ dewastacji natury, $\mathrm{w}$ totalitarnych ideologiach i innych przejawach kryzysu duchowości jednostki.

Istotę zła natury ludzkiej ${ }^{40}$ stanowi zatem wieczny niedostatek, „s u m a w s pó ln y c h o g r a n i c z e ń" "41, ułomność człowieka uzewnętrznia się zwłaszcza w przestrzeni kontaktu z drugim, jak i w kontekście zobowiązań wobec wyższego prawa.

Nie dość skupienia, nie dość oddania nie dość wyrzeczenia, nie dość współistnienia nie dość współmyślenia, nie dość rozumienia nie dosyć miłości nie dosyć tkliwości nie dosyć wielkości nie dosyć pokory nie dość wytrwałości zawsze winni zawsze skażeni zawsze potępieni [Zwątpienie, N 78]

„Kategoria rządząca pojęciem »grzechu« to kategoria »wobec« Boga” - zaznacza autor Symboliki zła. Ostatni wers Zwatpienia interpretuję więc w perspektywie teologicznej, gdyż winnym i potępionym w wymiarze "zawsze" 42 można być, odwołując się do słów Ricoeura, wobec Boga, czyli wobec prawa i złamanego nakazu, wobec wcześniejszego Przymierza. Hartwig eksponuje dramatyzm losu ludzkiego i tytułowe zwątpienie w możliwość dopełnienia projektu egzystencji, który pozostanie otwarty. Dialogiczny charakter istnienia wskazuje również na fakt, iż owa skaza, którą dotknięty jest człowiek, przejawia się w relacji z Drugim jako immanentna niepełność empatii. Wydaje się więc, że to przestrzeń między ludźmi wyznacza granice zła, zgodnie z poglądami Tischnera, który widział problem zła w kategorii dialogicznej. Nie jest ono zatem przedmiotem, bytem odrębnym

${ }^{40} \mathrm{O}$ współczesnych dyskusjach wokół rozumienia pojęcia natury ludzkiej zob. A. B i e li k - R o b s o n, Dzieci czasu i losu: ponowoczesne kontrowersje wokół natury ludzkiej. W: Inna nowoczesność. „Human nature” przedstawiana jest tu jako kategoria modernistyczna, autorka referując m.in. stanowisko H. Arendt, pisze: „Natura ludzka to człowiek w oczach Boga: to człowiek, który nic o sobie nie może wiedzieć na pewno, ponieważ każda jego mądrość jest tylko »głupstwem w oczach Bożych «. Kondycja ludzka natomiast to człowiek w oczach człowieka: najbardziej uchwytne, najbardziej rzucające się w oczy podobieństwa, ich dobrze znajoma powszechność i wspólnota, pospolitość »zwykłego ludzkiego nieszczęścia«" (s. 177). Idąc śladem tego rozróżnienia powołuję się na perspektywę teologiczną w interpretacji wierszy Natura twoja... oraz Zwątpienie. Zob. też: M. Z a l e s k i, Niewymuszona lotność i konieczny ciężar. „Res Publica Nowa” 2003, nr 2.

${ }^{41}$ B i e li k-R ob s o n, Dzieci czasu i losu, s. 168.

${ }^{42}$ R i c o e u r (op. cit., s. 50) pisze: „Tylko w wymiarze spotkania i dialogu, który jest wcześniejszy, może pojawić się coś takiego jak nieobecność i milczenie Boga, odpowiadające daremnej i wydrążonej egzystencji ludzkiej. Tylko to wcześniejsze ukonstytuowanie się więzi Przymierza ma wagę dla świadomości grzechu, to ono czyni z grzechu naruszenie Przymierza". 
wobec ludzkiej egzystencji, lecz zjawiskiem, w którym jednostka czynnie partycypuje. „Tylko człowiek jest podmiotem dramatu dobra i zła, ponieważ tylko człowiek uczestniczy w jednym i drugim; dzięki niemu, lub z jego winy, dobro i zło wkraczają w świat" - stwierdza autor Filozofii dramatu ${ }^{43}$. W tej perspektywie odsłania się wymiar etyczny życia jako wezwania do współistnienia.

Hartwig akcentuje więc dualizm natury ludzkiej, jej niepełność, zależność od wyborów i ograniczeń wolnej woli. Marzanna Bogumiła Kielar pisała o nieustannym dramacie ludzkiej egzystencji, jaki rozgrywa się w tej poezji ${ }^{44}$, gdzie człowiek na zawsze pozostaje wygnańcem z raju, śmiertelnym i obarczonym skazą:

\section{z dzikich łąk wydziedziczeni \\ pozdrawiamy stopami korzenie korzeni \\ kolebkę śmiertelności [Westchnienie, $\mathrm{Cz} 42$ ]}

Motyw wygnania ${ }^{45}$, które określa egzystencję ludzką, splata się tu z mitem wypędzenia z Raju. Jak się okazuje, wygnanie prowadzi do sensów metafizycznych i religijnych. Zło widziane jest jako pierwotna ułomność i niedoskonałość, wieczny brak i niedostatek. Jest także zwycięstwem chaosu nad ładem. W późnych wierszach w niepokojących obrazach przychodzi świadomość, iż życie to ,zimne stopnie wędrówki coraz mniej zrozumiałej" (Zona, T 24), a każdy z nas - pielgrzym, wygnaniec, uciekinier - wie, że ,tak ma być / że musi podążać” (Dokąd wędruja, T 38), zdając się na los i Niewiadome. $Z$ wiekiem więc autorka Dwoistości nie odnajduje ukojenia, stabilnej, duchowej przystani, jej poezja mnoży pytania i kumuluje niepokoje, tym silniejsze, im bardziej czas i przemijanie władają życiem.

U Hartwig świat jest obszarem dokonującej się katastrofy (tak w aspekcie poczucia kryzysowego charakteru współczesności, jak i odwiecznej „katastrofy” egzystencji, czyli przemijania i śmierci). Spełnia się ona na oczach podmiotu wierszy. Jest to więc poezja, z jednej strony, przeczuć końca, rozpoznania jego symptomów, z drugiej zaś strony - niezgody na kryzys, próby restytucji sensu, odnalezienia miejsca człowieka w świecie i ponownego zakorzenienia. „Hartwig słyszy przecież krzyk świata, dobiegający z ascetycznej traumy gotyku, z rozpaczliwej ekstazy baroku, z XIX-wiecznej demaskacji metafizyki, której ostateczną śmierć wieszczy stulecie współczesne" - pisze Piotr Łuszczykiewicz ${ }^{46}$. Doświadczenie nihilizmu, które pozbawiło świat zmysłu metafizycznego, jest jednym z kluczowych problemów, z jakimi usiłuje się zmierzyć autorka Czuwania, budu-

${ }^{43}$ T is ch he r, op. cit., s. 98.

${ }_{44}$ M. B. K i e l a r, O tomie ,,Zobaczone” Julii Hartwig. „Zeszyty Literackie” 2000, nr 1, s. 112.

${ }^{45}$ Wydaje się, że w poezji Hartwig dopełniają się dwie wersje tego motywu. Uogólniona kondycja współczesnego wygnańca ma swe korzenie także w indywidualnym, biograficznym doświadczeniu rodziny autorki Obcowania. Jej rodzice (Maria, z domu Biriukow, oraz Ludwik Hartwig) do 1918 r. przebywali w Rosji, gdzie ojciec od 1909 r. prowadził w Moskwie zakład fotograficzny. Tam też przyszło na świat starsze rodzeństwo Julii - Edward, Walenty, Zofia i Helena. Do przeniesienia się do Polski zmusiła rodzinę Hartwigów rewolucja bolszewicka. Emigracyjne losy rodziców może nie odcisnęłyby się tak silnym piętnem na świadomości poetki, gdyby nie tragedia jej matki, która, nie mogąc odnaleźć się w nowej dla siebie kulturze, popełniła samobójstwo. Jej postać oraz historia rodziny powracają w takich utworach, jak Zbudzenie w świetle łaski (Ch 18), Elegia lubelska (N 22), Na cześć moich braci (Z 47), Niepotrzebne skreślić (BP 8), a przede wszystkim w pięknym Przywoływaniu (BP 23) z tomu Bez pożegnania.

46 P. Łu s z c z y k i e w i c z, Być poeta osobnym. „Nowe Książki” 1998, nr 11, s. 4. 
jąc swój afirmatywny światopogląd ponad rozpaczą i dając odpowiedź na kryzys współczesności. Hartwig szuka więc takiej przestrzeni, w której istnienie obdarzone jest sensem. Sytuacje graniczne, dwoiste pojmowanie egzystencji, objawiają znamienne dla poetki ,prawo do sprzeczności” i chęć ich zespolenia.

Rozpacz się nie starzeje. Młoda i stara jednakowo żarłoczna.

[................. . . . . .

A przecież na przekór niej wołam: Radość! Joy!

Stan błogosławieństwa i lunapark dziecinny.

Iść koleiną losu w śpiewie niewidzialnych stworzeń.

Radość twarda jak diament, niezawisła i niczemu nic niedłużna.

Sprzeczność jest moim żywiołem, prawem, o które wojuję.

(Na wieczorze autorskim ktoś powiedziat że

moje wiersze sa petne rozpaczy, WW 217)

Łączyć to, co widzialne i niewidzialne, jasne i ciemne, w pełnej afirmacji życia, niezależnej od świadomości cierpienia i śmierci, co więcej - pełniejszej przez tę właśnie świadomość. Towarzyszy więc autorce Czułości uczucie ontologicznie warunkowanego rozdwojenia, poszukiwanie ładu poprzez sztukę, która wyraża potrzebę nadawania sensu ${ }^{47}$ wraz z jednoczesnym tragicznym przekonaniem o niemożności całkowitego oswojenia chaosu, ze świadomością istnienia ciemnej podszewki bytu.

\section{Po stronie ladu}

Analizując poezję Hartwig, Baranowska pisze:

W całej swojej twórczości Julia Hartwig stara się znaleźć odpowiednią miarę. Należy do tych poetów, którzy przez wieki kontynuują poszukiwanie harmonii; nie tylko harmonii dźwięków, języka, ale i harmonii świata. Wydawałoby się, że takich poetów trudno znaleźć w świecie współczesnym. Ale mimo poczucia mieszkańców XX wieku, że harmonia jest we współczesności nie do odnalezienia, a za naruszoną uważana była już w starożytności, tacy poeci istnieją ${ }^{48}$.

Wizja świata zdekomponowanego i nieharmonijnego, będąca elementem owych katastroficznych intuicji i rozpoznań, składa się na tragiczną diagnozę kondycji ludzkiej XX i XXI wieku. W tej perspektywie Hartwig podejmuje próbę przezwyciężenia owego kryzysu - dzięki poszukiwaniu trwałych podstaw harmonii i ładu. Podmiot wierszy autorki Zobaczonego jest tym, który, widząc spłaszczenie oraz zbanalizowanie ludzkiej egzystencji, wydaje negatywną ocenę duchowej kondycji człowieka, ale sam takich odczuć nie podziela. Wciąż podnosi natomiast wiarę w możliwość bycia w Całości i pragnienie wkomponowania się w „naturalny porządek" rządzący się prawami swej wewnętrznej logiki. Nie jest to jednak wiara łatwa, lecz zbudowana na tragicznym przekonaniu o konieczności jej dochowania. Znamienne dla Hartwig czynienie jakościowych rozróżnień, dualizowanie refleksji realizuje poetka powołując jedną z kluczowych dla siebie opozycji: ład-chaos. Jest ona podstawowym, niejako klasycznym sposobem postrzegania świata, pociągającym za sobą cały szereg konsekwencji. W dualistyczny układ wpiszą się

\footnotetext{
47 Zob. R. K. Przy by 1 s k i, Potrzeba sensu. „Twórczość” 1982, nr 5, s. 125.

${ }^{48} \mathrm{~B}$ aranowska, op. cit.
} 
wspomniane rozróżnienia pojęć dobra i zła, jasności i ciemności, takie kategorie, jak prawda, pamięć, czas, współistnienie oraz ich przeciwieństwa. Idea ładu u autorki Czułości zakłada także porządkującą rolę snu, poszukiwanie formy jako dopełnienia (a nie przeciwieństwa) nieokreśloności „,doświadczenia”, jako funkcji muzyki w ukazywaniu metafizycznej głębi świata, a przede wszystkim jako rytmu natury. W owej antynomii porządku i chaosu poetka zawiera zasadnicze pytania o strukturę świata i jego istnienie, o miejsce człowieka i jego wybory.

Hartwig, osadzając egzystencję na kulturowym filarze symboli, widzi ją jako „Ciemny las Dantego / lasy Szekspira”, a człowieka - jak już wspomnieliśmy - w kategorii pielgrzyma, wygnańca, dla którego jej poezja szuka zakorzenienia w bycie, próbując na nowo określić ludzkie locum (Jarząb, Z 84; Drzewo to dom, Z 27; Evergreen, Cz 95). Opis ludzkiego istnienia przez odwołanie się do symboli utrwalonych w tradycji okazuje się wiarygodniejszy niż jednostkowe świadectwo pamięci, wskazując na uniwersalność rozpoznań:

\author{
Ciemny las Dantego \\ lasy Szekspira \\ prawdziwsze niż cienie wspomnień \\ Suniemy \\ jak ofiarne woły z pozłacanymi rogami \\ całą siłę wkładając w budowanie wiary \\ że nie ulegniemy przemocy \\ Zamieć głód i wygnania \\ przetaczają się przez nas jak potężna fala \\ spod której wyłaniamy się nadal żywi \\ by oglądać krajobraz niespełnienia \\ Jedyny ratunek to utrzymanie rytmu \\ wizja harmonii \\ która bierze nas jak dzieci w swoje objęcia \\ niewinna matka pociechy $[W$ pochodzie, $\mathrm{BP} 18]$
}

Hartwig nie poprzestaje zatem na wskazaniu chaosu egzystencji. Los ludzki to wygnanie, ale osłodzone wiarą w ratunek, jaki niesie ,utrzymanie rytmu”. Wizja harmonii - „niewinna matka pociechy” - ma oparcie w nadziei, że istnieje jakiś naddany ład kosmiczny (wszak dla starożytnych Greków ład był główną zasadą wszechświata, nazywanego kosmosem), z którego ideą koresponduje już od antyku myśl o harmonii utożsamianej z takimi wartościami, jak zgodność, jedność, porządek. Obrona ładu stanowi więc odpowiedź na dojmujące poczucie destabilizacji świata. Wielu badaczom postawa ta umożliwiała sytuowanie Hartwig w obrębie szeroko pojętego klasycyzmu, ale jeśli jest to klasycyzm, to głęboko zraniony tragizmem istnienia i katastroficznymi lękami.

Wyobraźnię poetycką autorki Zobaczonego absorbują dwa żywioły, będące symbolami nieskończoności: morze i słońce, które porządkują i jednocześnie waloryzują przestrzeń na bieguny chaosu i ładu. Morze postrzegane przez Miłosza jako symbol nicości, żywioł bezgraniczny, bezkształtny ${ }^{49}$, u Hartwig jest siłą nie

${ }^{49} \mathrm{Cz}$. M iło s z mówi: „morze występuje zawsze jako żywioł, jako chaos, primordial chaos, element zasadniczo wrogi człowiekowi, bo bezgraniczny i bezkształtny. Przeciwstawiony jest temu człowiek jako kształt, myśl, rozum. To jest konflikt między Naturą i człowiekiem" (R. G o r c z y ń- 
tyle wrogą człowiekowi, co uosabiającą energię pierwotną, stwórczą i hipnotyczną w swej mocy ${ }^{50}$.

Kiedy zatoka morska cichnie, wydaje się, jakby cały świat się uspokajał. dnie.

Przezroczysta woda ukazuje czyste konstelacje kamyków odpoczywających na

I budzi się absurdalna nadzieja, że wszystko, co na świecie rozrzucone bezładnie, ułoży się znów w naturalnym porządku. [Wróżenie z morskich fusów, $\mathrm{Cz}$ 36]

Świadomość „absurdalności nadziei” wskazuje na poczucie zerwanej więzi $\mathrm{z}$,naturalnym porządkiem”, którego przywrócenie jest dziś utopijnym postulatem wcielenia idei, a owa wyższa instancja okazuje się dla nas niedostępna. Rozpoznanie struktury świata, przede wszystkim zaś ludzkiej egzystencji, przypomina więc wróżenie, czyli nie roszczące sobie miana pewności wysnuwanie wniosków na podstawie niejasnych przesłanek, przeczuwanie, czytanie symboli. Wróżenie jednocześnie odsyła do związku z profetyzmem, do tego, co ukryte przed władzami racjonalizującego rozumu. Anna Kałuża interpretowała ten utwór jako wyraz wiary w ,naturalny porządek rzeczy" ${ }^{51}$. Wydaje się jednak, że trafniejszy jest trop „absurdalnej nadziei [...]”, wskazującej na ambiwalentny charakter świadomości podmiotu, której częścią jest przekonanie o niemożności prostego przełożenia „konstelacji kamyków [...]” na to, co ludzkie i „rozrzucone bezładnie”. „Brak odpowiedzi dotyka sfery metafizyki, ale zakotwiczony jest przede wszystkim w horyzoncie ludzkiej egzystencji, która okazuje się epistemologicznie nieprzejrzysta" - dodaje Leokadia Hull ${ }^{52}$. Podmiotowi właściwe zatem jest nie poczucie zadomowienia $\mathrm{w}$ transcendentnej rzeczywistości ${ }^{53}$, ale modernistyczne poszukiwanie śladów naturalnego algorytmu świata, poczucie sprzeczności, wiara w swym sednie rozdarta. Bycie w Całości wydaje się więc możliwe tylko w przestrzeni projektu, horyzontu jednostkowego myślenia; odwołując się do słów Bielik-Robson, świat nie stanowi dla Hartwig domu, tylko musi być nim czyniony.

Istnieje wszakże przestrzeń, w której ład daje się odnaleźć i rozpoznać jako niepodważalny, wspiera się on przede wszystkim na porządku natury ${ }^{54}$, przemien-

s k a〈E. C z a r n e c k a〉, Podróżny świata. Rozmowy z Czesławem Miłoszem. Komentarze. Kraków 1992, s. 173-174).

50 Zob. W. K o p a li ń s k i, Stownik symboli. Warszawa 2006, s. 230-231: „Morze jest symbolem nieskończoności, czasu, wieczności; pramaterii, Chaosu, (s)tworzenia świata; potęgi; otchłani, topieli, [...] stanu między możliwością a rzeczywistością, [...] prastworzenia, niezgłębionej mądrości i prawdy, początku życia”. U Hartwig motyw akwatyczny odgrywa istotną rolę (wspomnieć należy choćby takie utwory, jak: O morzu, W 73; Taras nad morzem, O 98; Czuwanie nad zatoka, C 45; *** (To prawda...), Ch 22). W poezji tej morze staje się symbolem zarówno dwoistego pojmowania własnej egzystencji, jak i antynomicznych sił składających się na strukturę świata (i kreacyjnych, i niszczycielskich).

${ }^{51}$ A. K ał u ż a, Wola odróżnienia. O modernistycznej poezji Jarosława Marka Rymkiewicza, Julii Hartwig, Witolda Wirpszy i Krystyny Miłobędzkiej. Kraków 2008, s. 107.

${ }^{52}$ L. H u 11, ,Bądź wdzięczna byłaś hojnie obdarzona”-Julia Hartwig. W: Obecność nieprzynależna. Pokoleniowe wydziedziczenie w poezji po 1989 roku. Olsztyn 2010, s. 210.

${ }_{53}$ Zob. R. N y c z, ,, Wyrażanie niewyrażalnego" w literaturze nowoczesnej (wybrane zagadnienia). W zb.: Literatura wobec niewyrażalnego. Red. W. Bolecki, E. Kuźma. Warszawa 1998.

${ }^{54}$ J. M a d e j s k i (W hołdzie światu. „Nowe Książki” 2005, nr 3, s. 10) w recenzji tomiku Bez pożegnania stwierdził: „Właściwie opiewanie stworzenia ogranicza się tu do jednego, Julia Hartwig koncentruje uwagę na rytmie natury. [...] Formuła Hartwig jest ascetyczna. Poetka nie tyle kieruje 
ności pór roku, następujących po sobie fazach dnia i nocy oraz wędrówce słońca, będącego strażnikiem owego ładu. W bogatej, tak judeochrześcijańskiej, jak i grecko-rzymskiej tradycji symboliki solarnej można szukać śladów metafizycznego postrzegania świata jako celowego ładu ${ }^{55}$. Autorka Zobaczonego wprowadza czytelne wartościowanie przestrzeni, operując kategoriami takimi, jak sfera zmierzchu i jasności, rejony cienia i widm, wiedząc, że „,wahadło wciąż się porusza z mroku w światło / ze światła w mrok" (Zanim, Z 34). Słońce odgrywa w poezji Hartwig istotną rolę dzięki metaforycznej dwubiegunowości, raz będąc jasnym znakiem nieskończoności, to znów ciemnym symbolem śmierci, zmierzchu oraz metafizycznego strachu ${ }^{56}$. W semantycznym polu słońca znajdą się również takie słowa-klucze, jak „,́́wiatło”, „błyskawica”, ,gwiazda”, ,złoty róg”. Doznanie jasności, obraz oślepiającego słońca, powraca niejednokrotnie w epilogach wierszy, stając się pomostem od konkretu przedstawienia do znaczeń metaforycznych, jako przebłysk „pełni metafizycznej” (Co wczoraj jeszcze, O 77; Mijanie się, D 26; Witaj, świetliku stońca..., Ch 54; Jeśli, C 33; Tyle tylko, C 30; Serce dnia, T 20; Odwiedziteś mnie, przebiśniegu..., Ch 24; Jest taki plac, Ch 70) ${ }^{57}$. Promienne słońce, strażnik ładu, które wszystko widzi i słyszy, jest świadkiem i kreatorem życia, gdy podmiot wiersza Wciąż jeszcze (Ch 7) wyznaje: „Ale rozpoznało mnie słońce. Mówi: pamiętam, wszystko pamiętam", słońce stanowi o ciągłości historii ludzkiej. Autorka Pożegnań nie unika retoryki wzniosłości ${ }^{58}$, gdy chce wyrazić przeżycie najwyższej afirmacji istnienia:
O serce dnia słońce bijące w nas i poza nami
Wszystko co żyje niech będzie żywe naprawdę
W jego równym biciu jest wolność i niezależność
a w jego wschodach i zachodach jest porządek naturalny
przeciw któremu się nie buntujemy
O wielka radości odczuwania smutku i cierpienia
O doświadczenie które krążysz w naszych żyłach
Co z tobą począć? Co począć? [Serce dnia, T 20]

\begin{abstract}
uwagę na estetykę, ile podsuwa argument filozoficzny: świat istnieje obiektywnie, a zatem ma sens uprzedni wobec nas".

${ }_{55}$ Zob. H. B u c z y ń s k a - G a r e w i c z, Poludnie. W: Metafizyczne rozważania o czasie. Idea czasu w filozofii i literaturze. Kraków 2003. Autorka wskazuje długą literacką tradycję motywu słońca, poczynając od Przemian O w i d i u s z a, przez Boska Komedię D a n t e g o, po filozoficzne rozważania na temat, ,wiecznego powrotu” w dziełach F. N i e t z s c h e g o (w szczególności Ecce homo i Tako rzecze Zaratustra).

${ }^{56}$ Zob. K o p a 1 i ń s k i, op. cit., s. 392: „Słońce wiąże się ze światem podziemnym i śmiercią [...]. Czarne Słońce, przebywające w nocy w innych, podziemnych krajach, w niektórych kulturach indiańskich oznacza śmierć i nieszczęście (wyobrażane w postaci jaguara); w nowożytnej literaturze i sztuce występuje niekiedy jako symbol smutku i metafizycznego strachu". Zaćmienie Słońca jest przecież także zapowiedzią dnia Sądu Ostatecznego: „Zaraz też po ucisku owych dni sło ń c e s i ę z a ć m i i księżyc nie da swego blasku; gwiazdy zaczną padać z nieba i moce niebios zostaną wstrząśnięte" (Mt 24, 29).

57 A. M o r a w i e c (Parnas $\langle$ izm 〉 Julii Hartwig. „Nowe Książki” 2008, nr 3, s. 66) w recenzji tomiku To wróci potwierdza to rozpoznanie: „Staroświecka kategoria estetyczna, jaką jest piękno kiedyś w tomie Dwoistość (1971) na chwilę spowita przez noc, sen, ciemność - od lat jednak uparcie wspierana przez motyw słońca, światła, jasności, muzyki, pieśni, wciąż pozostaje dla poetki narzędziem dochodzenia do tyleż estetycznej, co metafizycznej pełni”.

${ }^{58}$ Zob. J. Płu c i e n n i k, Retoryka wzniostości w dziele literackim. Kraków 2000.
\end{abstract}


W rytmie natury przejawia się tajemnica bytu, słońce - symbol życia, wyznacza rytm istnienia, stanowi centrum, wokół którego krąży wszelkie żywe stworzenie. Pochwalna inwokacja wskazuje na afirmatywne doświadczenie porządku świata, odsłaniając mistykę słońca stojącego w zenicie. Wiara w możliwość znalezienia jedności z harmonią natury jest tym, co pozwala stawić czoła tragicznemu wymiarowi egzystencji, której witalistyczna ciągłość niesie pocieszenie w świecie zagrożonym nicością.

Motyw słońca i światła nie wyczerpuje się w afirmacji porządku Natury. Ma też podbudowę metafizyczną, gdyż jasność i świetlistość wydobywa się również stamtąd, skąd przybywają duchy zmarłych (,,i takie światło obezwładniające / spoza wszystkiego / stamtąd gdzie jesteście" - Ta chwila, T 28). Podobnie u Dantego obraz raju nosi znamiona wszechogarniającej jasności: „Całe doświadczenie raju jest przepojone światłością, niebo jest jednym niezmierzonym ogromem świetlnym. Obraz oślepiającego słońca w zenicie stale powraca" - pisze Hanna Buczyńska-Garewicz ${ }^{59}$. Hartwig nie czyni wyznania wiary, powściągliwie mówi o przestrzeni niewyrażalnego, niczego nie nazywa wprost, utrzymując jednak pewność, iż owa sfera istnieje i przenika w świat realny. O ile imię Boga przywołuje się sporadycznie, to świadomość obecności zmarłych jest tym, co konstytuuje głębię rzeczywistości.

Solarna pełnia wprowadza do tekstów Hartwig moment zatrzymania bytu $\mathrm{w}$ bezczasie trwania przemienionego $\mathrm{w}$ wieczność. W poemacie prozą $Z$ odwrócona głowa, w którym spotykają się żywioły morza i słońca, czytamy:

Kiedy już wszystko minie, kiedy nacieszę się już tym, co mnie raduje, że jest i trwa, chciałabym być posągiem patrzącym w morze, bez imienia, bez nazwy, stojącym z głową odwróconą od wszystkiego, co nudzi i trapi.

Za plecami mieć ciemność, przed sobą rozświetlone niebo, ruchliwe światła na wodzie, na kamiennej twarzy czuć południowe słońce. [Cz 113]

Poetka nosi w sobie wizję pierwotnej struktury świata, opozycyjnej wobec skażonej chaosem i bezładem współczesności. Mityczny raj to zwycięstwo porządku i harmonii:

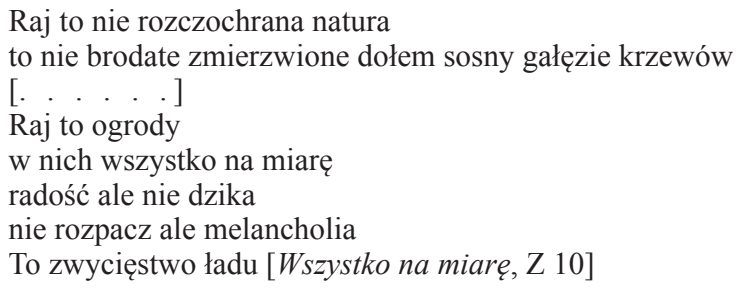

Symbolizują go klasycystyczne, a nie barokowe, ogrody, będące zarazem synonimem kultury. Raj widzi zatem Hartwig jako swoiste ujarzmienie tego, co „ponad miarę”. To azyl i bezpieczeństwo, zapewnione przez przewidywalność linii i kształtów, przez dystans, który rodzi melancholię i staje się tryumfem świadomości. Jej symbolem poetka czyni ogród, wykorzystując jedną z jego semantycznych potencji. Ogród, stanowiący przeciwieństwo lasu („,brodate zmierzwione dołem

${ }^{59}$ B u c z yń s ka-G a rewi c z, op. cit., s. 147. 
sosny [...]”, jest opatrzonym długą tradycją znakiem świadomości ${ }^{60} \mathrm{i}$ zarazem miejscem, w którym nad prawem przyrody przeważa ,jasność dnia”, będąca domeną kultury. Obraz natury uporządkowanej wskazywałby na kulturotwórczą działalność człowieka. Ostatnie trzy wersy utworu wprowadzają jednak znaczące rozróżnienie:

cóż z tego że na żwirowanych ścieżkach posłyszysz czasem zbliżające się kroki nad którymi nie zdążyło jeszcze ukształtować się ciało [Wszystko na miarę, Z 10]

Raj ten okazuje się niedostępny cielesnemu człowiekowi. W potencjalności kreacji ludzkiej wiersz zbliża się do Leśmianowskiej Ballady bezludnej. Obraz natury możemy jednak uznać za diametralnie odmienny: u autora Dziejby leśnej, zgodnie z Bergsonowskim elan vital, jawi się ona jako nieujarzmiona, dzika, witalistyczna; u Hartwig zaś jest harmonijna, poddana rygorowi formy.

Realną przestrzeń natury lokuje poetka w przestrzeni arkadyjskiego mitu. Nie zgodzę się jednak z Leokadią Hull, że Arkadia ta trwała nietknięta przez siły czasu i przemijania ${ }^{61}$. Przeciwnie, jest to Arkadia obarczona gorzką świadomością śmierci, jak w poemacie Obcowanie (Ch 34):

Bukiet z kwitnących pokrzyw. Wąsaty, tatarski, dziki.

Połysk żółtych źrenic, fioletowe białka. Mlecze drzemią w zieleni.

Na margerytkach znać już przedśmiertne zmęczenie. Znamy je, co rok je mijamy,

kiedy beznadziejnie chore, ciężko dysząc, z włosem rzadkim i zlepionym patrzą z pościeli w oczy śmierci, która przychodzi w pełni słońca, w zasłonie pszczół, sobowtór samego lata, rumiana, nie do rozpoznania w swoich zamiarach [...].

\section{- czy w wierszu Zraniony (Cz 12):}

O pełnia niezwyciężona pełnia lata tryumfująca a tak żałobna tak bliska śmierci ukazująca zenit i kres

zanim jeszcze wszystko stanie się oczywiste

Obraz poetycki nigdy nie jest statyczny, tylko niejako zatrzymany w chwili przed wybuchem, zawiera w sobie ładunek eksplozyjny, zalążek kresu. Hartwig wie, że świat nawet w momencie najwyższego wyniesienia przełamuje się w pół, chyli się ku upadkowi już w największym rozkwicie. Pisze zatem o utraconej przez ludzi harmonii, poszukując jej śladów w naturze. Brak ładu w sferze egzystencji wyraża nostalgia za prostymi i elementarnymi wartościami (Westchnienie, Cz 41). Zaginionej Arkadii nie odnajduje autorka Dwoistości nawet we wspomnieniu dzieciństwa (Żadnych rajów, Z 45), które znaczone jest utratą, sieroctwem.

Idea ładu objawia się także poprzez funkcję nadaną muzyce, rozumianej zarówno jako zamierzone dzieło ludzkie, jak i harmonijne dźwięki natury ${ }^{62}$. Muzyka,

${ }^{60}$ W Stowniku symboli K o p a 1 i ń s k i e g o (op. cit., s. 270) czytamy: „Ogród - świadomość, przeciwieństwo lasu - podświadomości. Ogród to miejsce, gdzie Natura jest odgrodzona, ujarzmiona, wyselekcjonowana; las jest miejscem, gdzie Natura jest swobodna, samowładna".

${ }^{61} \mathrm{O}$ micie arkadyjskim w poezji Hartwig zob. L. Hu 11, Arkadyjskie pejzaże Julii Hartwig. W zb.: Święte miejsca w literaturze. Red. Z. Chojnowski, A. Rzymska, B. Tarnowska. Olsztyn 2009, s. 166.

${ }^{62}$ Piszę o muzyce w twórczości Hartwig tylko w tym aspekcie, który wyraża jej funkcję porządkującą i ,ustanawiającą poczucie harmonii”, czyli w sensie egzystencjalnym, co, oczywiście, nie wyczerpuje zagadnienia. Z przekonaniem odsyłam natomiast do artykułu J. W iśn i e w s k i e- 
która wiąże się tu z klasycznymi wartościami (pięknem, dobrem, harmonią), od starożytności nierozerwalnie złączona była z poezją. Zgodnie z tradycją pitagorejską upatrywano w niej ideę harmonii i postrzegano ją jako element kosmicznego porządku. W wierszach autorki Czułości znamiona słuszności takiej interpretacji dostrzegamy od debiutanckiego tomu Pożegnania, w którym czytamy, że „Wszystko co piękne zaczyna się w śpiewie" (Wiosenne światto, P 58). W innym wierszu przyznaje Hartwig muzyce status wyrazicielki ludzkich dziejów i najgłębszej prawdy życia, stojącej za pozytywnością istnienia:

\author{
To jest muzyki wielki przeciąg, \\ Który się za historią wdziera. \\ Kochamy ją. Kochamy życie \\ I to, co w życiu nie umiera. [W pochodzie muzyki, $\mathrm{P} 40]$
}

W muzyce doszukuje się zatem funkcji porządkującej, która pozwala oddać harmonię i przeczucie metafizyczne. Autorka Blysków byłaby tym samym bliska romantycznym poglądom o muzyce jako bezpośrednim i najbardziej pierwotnym nośniku istoty bytu ${ }^{63}$. „Wszyscy poeci świata piszą jeden wiersz” (Wbrew sobie, N 8), starając się wypowiedzieć Tajemnicę, sięgnąc rdzenia egzystencji - przyznaje w późnym tomie Nie ma odpowiedzi.
W tej wielkiej symfonii którą wykonują
tylko pierwsi skrzypkowie zaszczycani są uściskiem ręki dyrygenta
i choć wszyscy poddani są prawom tej samej harmonii
każdy z nich chciałby być kochany z osobna [Wbrew sobie, $\mathrm{N} 8$ ]

„Wielka symfonia” (jako muzyczna metafora struktury świata), w której uczestniczą poeci, podlega jednej sile sprawczej. Ideał harmonii przejawia się w poetyckim bądź muzycznym geniuszu największych twórców, którzy są w stanie dziełem swym sięgnąć pozazmysłowej pełni. Rangę takiego artysty zyskuje Johann Sebastian Bach, którego kompozycje oddają doskonałość uniwersum metafizyczności.

\author{
Gdybyśmy kochali go naprawdę potrafilibyśmy stworzyć tę kantatę \\ Niech nikt nie mówi że nie zna nut i że ma tępe ucho \\ Gdybyśmy go kochali jak na to zasługuje \\ umysł nasz osiągnąłby wiedzę o harmonii w jednym momencie objawienia
}

\begin{abstract}
g o (Obraz tradycji muzycznej w wierszach Julii Hartwig. W zb.: Polska proza i poezja po 1989 roku wobec tradycji. Red. A. Główczyński, M. Wróblewski. Toruń 2007), który podjął się wstępnego rozpoznania odniesień muzycznych występujących w tej poezji.

${ }^{63}$ Mam tu na myśli owe poglądy w tym idealistycznym ujęciu, abstrahującym od problematyki formy i semantyki muzycznej, jakie E. B i eńkowska (Wprowadzenie: Muzyka w świetle myśli idealistycznej. W: W poszukiwaniu królestwa człowieka. Utopia sztuki od Kanta do Tomasza Manna. Warszawa 1981), analizując porównawczo miejsce oraz funkcje muzyki w estetyce romantycznej i klasycystycznej, określiła swoistym „mitem pocieszycielskim” poetów romatycznych, widzących w muzyce spełnienie bezpośredniości wyrazu, ponad ograniczeniami słowa. W rozdziale Muzyka w świecie myśli idealistycznej czytamy: „Tak więc muzyka, odbicie życia wewnętrznego i rewelacja tajemnic bytu, z bardzo pośledniego miejsca w klasycznych estetykach wyniesiona została na szczyt. [...] Dusza więc miała naturę muzyczną i muzyczna też była osnowa świata, poeta w swych najlepszych momentach był właściwie muzykiem, a każdy, kto doświadczył silnych uczuć, metafizycznych, miłosnych, religijnych, roztapiał się w żywiole muzyczności i tylko poprzez nią mógł wyrazić swoje doświadczenia" (s. 179).
\end{abstract}


i stalibyśmy się jedną muzyką i jednym chórem głosów

wołających Chwała Chwała

gdybyśmy kochali go jak nam przykazał [Kantata Bacha, Cz 90]

Hartwig subtelnie opowiada się za pozytywnością istnienia świata, którego afirmacja wyrasta ponad świadomością kryzysową. Odwołując się do idei harmonii, oddanej m.in. przez ład przyrody, poetka pragnie przywrócić wiarę w sens istnienia. Prócz wartości związanych z duchem klasycyzmu należy zauważyć, że nieobce tej autorce są także romantyczne korelacje miłości i objawienia, harmonii i muzyki, które ukazują duchowy wymiar istnienia.

\section{„Nie ma odpowiedzi"}

Ale sztuka może być katapultą, może odsyłać do treści metafizycznych, może prowadzić do rzucenia światła na tajemnicę życia ${ }^{64}$.

Sztuce, a zatem również poezji, przypisuje Hartwig zdolność do wyrażania głębi istnienia, do oświetlania w sposób niedogmatyczny, a polegający na wewnętrznym przeżyciu i konkrecie, tego, co niedostępne w dyskursie naukowym. Podstawowe dla autorki tomiku pt. Nie ma odpowiedzi doświadczenie istnienia $\mathrm{z}$ nieodłącznym mu doznaniem sacrum stanowi jednocześnie w jej utworach źródło treści metafizycznych ${ }^{65}$. Jeśli metafizykę i transcendencję rozumiemy najogólniej w duchu Lévinasowskim jako zwracanie się ku temu, co ,inne”, ku temu, co „poza”, jako „ruch wychodzący od świata, który jest nam bliski i znany”, ku temu, co obce, ,poza mną", ku „tam” ${ }^{66}$, to poezja Julii Hartwig pozostaje metafizyczna także w tym znaczeniu, w jakim wykracza poza to, co zmysłowo doświadczalne i racjonalne, próbując określić miejsce człowieka w świecie podległym prawom śmierci i przemijania oraz mierząc się z niewyobrażalnym. Nowoczesność przyniosła zasadniczy kryzys totalności i tradycyjnie rozumianej metafizyki ${ }^{67}$, a w na-

${ }^{64}$ Ciekawość świata. Z J. Hartwig rozmawiała A. K o s s. „Kresy” 1997, nr 1, s. 115.

${ }^{65}$ Precyzując przedmiot metafizyki, W. S tróże w s ki (Wokół piękna. Szkice z estetyki. Kraków 2002, s. 96) zaznacza, że we wszystkich historycznych ujęciach pojawiają się jej trzy nieodzowne elementy: podstawowość, byt i transcendencja. Badacz uściślając terminologicznie określenia takie, jak metafizyka sztuki, metafizyczność sztuki i metafizyczność w sztuce, rozumie tę ostatnią jako próbę wyrażenia najgłębszego „doświadczenia istoty (głębi) istnienia albo Transcendencji, w szczególności zaś Transcendencji w immanencji (czyli w granicach bezpośrednio danego nam świata), albo istoty naszej egzystencji, transcendującej ku swemu ostatecznemu przeznaczeniu i nieuchronności śmierci" (s. 120). Piszę więc o poezji Hartwig jako o poezji metafizycznej w tym zakresie, w jakim ujawnia ona treści metafizyczne. Istotne jest dla mnie także stanowisko M. D ąbrow sk i e g o (Trzy utraty. I trzy pożytki. W: Projekt krytyki etycznej. Studia i szkice literackie. Kraków 2005), który abstrahuje od wyłącznie religijnej interpretacji metafizyki, twierdząc, że może być nią również ,jakiś rodzaj wartości, doświadczenia, świata, który jest praktycznie idealnym wyobrażeniem, czymś, co wyzwala w jednostce potrzebę przekroczenia granicy tabu, wzniosłości, stawia w obliczu niewyrażalnego itp." (s. 70).

${ }^{66}$ Zob. Od Husserla do Lévinasa. Wybór tekstów z ontologii fenomenologicznej. Red. W. Stróżewski. Kraków 1987, s. 302.

${ }^{67} \mathrm{M}$. D ą b row s k i (Literatura XX wieku w perspektywie porównawczej: modernizm, awangarda, postmodernizm. 〈Rekonesans〉. W: Projekt krytyki etycznej, s. 119-120) zauważył: „, n i k a samoistny, metafizyczny horyzont sensu. [...] Zmienia się ontologia obu istotnych członów, zarówno »sens«, jak i »metafizyka« podlegają daleko idącej metamorfozie. Sens, jak po- 
stępstwie zwątpienie w naddaną strukturę i w sens. Poezja Hartwig w swym dążeniu nie cofa się do przednowoczesnych kategorii metafizyczności, ujawnia natomiast przyrodzoną człowiekowi tęsknotę metafizyczną. Tęsknota ta łączy się z większym projektem poznawczym, wynikającym z nowych ról i postrzegania podmiotu, który można widzieć w perspektywie filozofii kondycyjnej ${ }^{68}$. Autorka Czułości przyjmuje kilka fundujących założeń: jest to przekonanie o obiektywnym istnieniu świata i zarazem o konieczności wyższej sankcji jego istnienia, potrzeba uwewnętrznienia jego obrazu na drodze poznania, co za tym idzie, podniesienie roli samoświadomości oraz wolnej woli w rekonstrukcji zerwanej, acz możliwej do odtworzenia (choć już tylko w jednostkowej perspektywie) więzi człowieka z utraconym porządkiem. ,„Dyskretny klasycyzm«, czyli przez ponowoczesność przezierający duch tęsknoty za całością (która - pisze Zagajewski - »istnieje, ale nie jest kompletna $)$, tęsknoty za sensem i ładem wewnętrznym", zostaje uwikłany w ,romantyczne dopełnienie" podmiotową epifanią ${ }^{69}$.

Całościowy ogląd dzieła Hartwig pozwala zarysować dwie tendencje w kształtowaniu doświadczenia metafizycznego ${ }^{70}$, właściwe poszczególnym okresom rozwoju tej poezji. W pierwszym z nich maksymalistyczne dążenie, by dotknąć rzeczywistości z wszystkich stron, prowadzi do przekroczenia jej w kierunku transcendencji. Autorka Zobaczonego czyni to niejako bez koniecznych i sankcjonujących odniesień religijnych czy filozoficznych (które pojawiają się dyskretnie, rzadko wywoływane, częściej natomiast poezja ta pozostaje na pewnym poziomie uogólnienia). Następnie twórczość Hartwig ewoluuje od wieloperspektywicznego

wiedziałem, nie jest dany, lecz musi być stale wypracowywany, wykuwany w procesie myślenia, działania, konfrontacji, dialektyki itd., poza tym nie jest czy też nie bywa wyłącznie metafizyczny. Tradycyjnie metafizyka kojarzona była z Bogiem, boskością i w ogóle sferą religii. Jednakże od oświecenia poczynając, a już przynajmniej od połowy XIX wieku, kiedy nasilają się wpływy filozofii materialistycznej, takie jej rozumienie przestaje być oczywiste. Trzeba więc inaczej pojmować metafizykę: jako poszukiwanie źródeł, jako określanie miejsc, w których może się ona realizować, sposobów nowego rozumienia, innego rozumienia ludzkiego bytu wobec tej oczywistości, że nie jesteśmy już więcej traktowani jako »dzieci Boże« itp. Metafizyką jest więc teraz to, co chcemy uznać za metafizykę, przeważnie chodzi o sytuacje, zdarzenia, prawa, zachowania, których racjonalności nie jesteśmy w stanie przeniknąć ani nazwać, co wymyka się oznaczeniom ostatecznym. Za metafizyczne uznajemy np. czas, którego natura nie daje się do końca zgłębić i opisać, lub ciało ludzkie bądź fenomen myślenia czy pamięci albo piękno - słowem kwestie czy doświadczenia, które dawniej wchłaniała, a często unieważniała metafizyka Boga, gdyż wszystko było w nim i z niego. Ta monometafizyka rozsypała się w wielość osobnych metafizyk, z którymi boryka się myśl nowoczesna tworząc swoje nowoczesne polimity".

${ }_{68}$ Filozofia kondycyjna - jak pisze B i e 1 i k - R o b s o n we Wprowadzeniu do Innej nowoczesności (s. 9-10) - „odsłania żmudne wysiłki człowieka, który, niczym Lévi-straussowski bricoleur, z tego świata-prawie-nie-do-życia tworzy swój w miarę stabilny i w miarę bezpieczny Lebenswelt. Wbrew powszechnym dziś zachwytom nad egzystencją w stanie flux et vertigo, podtrzymuje ona przekonanie, że receptą na przeżycie w modernitas nie jest bynajmniej bezwarunkowa akceptacja jej wartkiego strumienia, lecz silny s ubiektyw ny opór".

${ }^{69}$ L e g e ż y ń s k a, Krytyk jako domokrążca, s. 20.

${ }^{70} \mathrm{O}$ zasadności takiego określenia przekonuje Stróżew ski (op. cit., s. 99): „O ile [...] w tradycji klasycznej analiza bytu w aspekcie istnienia nie miała wykraczać poza dziedzinę ściśle określonej racjonalności [...], to w niektórych ujęciach współczesnych podkreśla się potrzebę swoistego poznania czy doświadczenia metafizycznego, które niekoniecznie pokrywać się musi z poznaniem ściśle racjonalnym". Badacz dodaje, że w ten sposób została otwarta droga do nowego pojęcia metafizyczności, wywiedzionego już nie z przedmiotu, lecz z doświadczenia metafizycznego. 
zgłębiania świata w kierunku kontemplacji szczegółu i „mistyki” rzeczywistości, by w ostatnim okresie rozbrzmieć mocniejszym tonem jawnie podnoszonej metafizyki i refleksyjności, wywiedzionej z tejże koncepcji rzeczywistości. Poetka żywi więc przekonanie o istnieniu pewnego naddanego, choć ukrytego porządku, co stawia ją w opozycji do wszelkich postmodernistycznych formuł znoszących taką perspektywę postrzegania. Owo „przeświecanie” wyższego sensu pozwala jednocześnie w sposób nieskrępowany afirmować rzeczywistość widzialną w całej jej niezmierzoności.

\section{Oniryczne meta-światy}

Już w tomie Wolne ręce silnie zaznaczyły się przekonanie o istnieniu, ,świata zakrytego", niematerialnej podszewki rzeczywistości, czy, jak deklaruje Hartwig, wiara w to, że rzeczywistość ma ,inne ukryte sensy”. To przekonanie będzie odtąd stanowić także podstawę dyskursu epifanicznego. Przywołane w wierszu Pod ta wyspa... skała, powietrze i woda, jako określenia żywiołów kosmicznych, spinają łuk ręki pływaczki, odzwierciedlając tym samym dążenie do zaznania jedności ze światem, ukazanej dzięki scaleniu rozdartego Bytu, połączeniu sfer realnej i idealnej ${ }^{71}$.

Pod tą wyspą jest inna wyspa, może jeszcze piękniejsza.

Ku niej szybuje uśmiechnięta pływaczka, łącząc błyskawicznym łukiem skałę, powietrze i wodę.

Chciałabym widzieć cię naraz ze wszystkich stron, stworze, fragmencie, zawierucho, wspaniały obłędzie jasnego umysłu. [Pod ta wyspa..., W 17]

Ów jeden z „wierszy-znaków” 72 , właściwy przemyśleniom poetyckim z wczesnego okresu twórczości Hartwig, nie prezentuje kategorycznych stwierdzeń, lecz, jak to w tej poezji bywa, pozostaje na granicy możliwości i poznawczego postulatu. Wyspa zgodnie ze swą symboliką wyobraża centrum, Kosmos w zmniejszeniu, kompletny i doskonały ${ }^{73}$, ku któremu zmierza „uśmiechnięta pływaczka”. Hartwig jednak nie ogranicza się do tradycyjnych znaczeń, podąża dalej, mnożąc światy realne i idealne. „Inna wyspa, może jeszcze piękniejsza” jest przecież marzeniem o swoistej utopii, poszukiwaniem drugiej rzeczywistości, świadectwem wiary, że świat nam dany nie jest światem jedynym ${ }^{74}$. Utwór pozostaje na styku onirycznych sprzeczności, oksymoroniczny „obłęd jasnego umysłu” pojawia się w zetknięciu z ogromem tego, co „poza mną”, z doznawaną ,nieobjętą” rzeczywi-

${ }^{71}$ Zob. też S molk a, op. cit.

72 Tak m.in. utwór Pod ta wyspą... określiła sama autorka (, Sztuka jest zaklinaniem istnienia” - jubileusz literacki Julii Hartwig. Rozmawiają: J. H a rtw ig, W. K a lis z e w s k i oraz I. S molk a. „Tekstualia” 2010, nr 1, s. 174).

${ }_{73}$ Zob. Kopalińs ki, op. cit., s. 489.

${ }^{74} \mathrm{Cz}$. M i ł o s z, z którym Hartwig wielokrotnie podkreślała swoje pokrewieństwo duchowe, wypowiada analogiczną myśl w utworze Zen codzienny z tomu Dalsze okolice (Kraków 1991, s. 68). Przekonanie o istnieniu i jedności wielu odmiennych jakościowo rzeczywistości wyraża tymi słowami:

Nigdy nie uważaj

tego świata za jedyny.

Następny i jeszcze następny...

Wszystkie światy są tu, teraz. 
stością, bezkształtną, a zarazem w spostrzeżeniu fragmentaryczną, która przeradza się w pragnienie zmysłów i rozumu. Poemat, ufundowany na metaforyce przestrzeni, wyzyskuje w jej konstrukcji oraz sposobie kojarzenia konwencję snu, charakterystyczną szczególnie dla pierwszych tomów poetyckich Hartwig. Marcin Telicki pisze:

Oniryczność niedogmatyczną (a więc niepoddaną założeniom surrealizmu, konkretnej doktrynie awangardowej czy nawet własnej teorii) można zatem traktować jako opis mający prowadzić do zrozumienia drugiego człowieka lub samego siebie, który rządzi się zmiennymi proporcjami (niezależnymi od normy dnia) ${ }^{75}$.

Dodajmy, że może to być także opis prowadzący do pewnej prawdy o złożoności i wielowymiarowości świata, opis, którego sednem często staje się nie tyle tematyzowanie snu, ile świadome wyzyskiwanie właściwej mu logiki obrazowania i kompozycji do tworzenia rzeczywistości równoległej wobec świata realnego. Poetyckie sny i konwencja oniryczna u Hartwig są więc tropieniem ,formuł egzystencjalnych”, ale i funkcją „,dociekliwości poznawczej”76. ,„)Ostrze snu« staje się bronią człowieka w walce poznawczej ze światem. Pozwala odrzeć istotę rzeczy z zewnętrznych osłon, ujrzeć rzeczywistość »naraz ze wszystkich stron «" - komentuje Stanisław Barańczak ${ }^{77}$. W próbie racjonalnego oglądu i w mrokach snu szuka więc poetka drogi do ukrytego wymiaru rzeczywistości, starając się pogodzić to, co zostało rozdzielone: władze poznawcze rozumu ze sferą nieświadomości ${ }^{78}$. W tym samym tomie, wraz z poczuciem nieograniczonego bogactwa przestrzeni, pojawia się rozpoznanie świata jako planu ,gigantycznej świątyni”, do której wertykalnie wiodą ,schody obliczone na krok bogów”, a wstąpienie na nie odbywa się poprzez wdarcie się w szczelinę bytu. To ostatnie znaczone jest w sposób zdynamizowany pierwotnymi, kosmicznymi żywiołami:

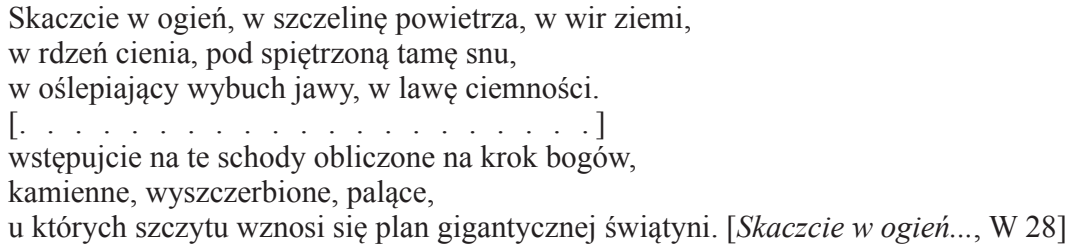

Staranie się o perspektywę absolutną, o objawienie istoty rzeczy poprzez skok w wir egzystencji, by odsłoniła się ona w pełni i obnażyła swój „rdzeń”, prowadzi Hartwig do sytuacji granicznych, do wypatrywania pęknięć, szczelin, olśnień, dzięki którym nagle może ukazać się owo „światło”, będące synonimem przebły-

75 Telicki, op. cit., s. 96.

${ }^{76}$ Zob. też J. K w i atkow s k i, Dwie poezje Julii Hartwig. W: Notatki o poezji i krytyce. Kraków 1975, s. 152.

${ }^{77}$ S. B a r a ń c z a k, Tajemna wiedza snu. W: Ironia i harmonia. (Szkice o najnowszej literaturze polskiej). Warszawa 1973, s. 137.

${ }_{78}$ A. L e g e ż y ń s k a (Od kochanki do psalmistki... Sylwetki, tematy $i$ konwencje liryki kobiecej. Poznań 2009, s. 260) uważa, że poetka „nie ryzykuje nicowania podszewki świata”. To stwierdzenie z pewnością można odnieść do późnych wierszy autorki Dwoistości, lecz nie wydaje się słuszne w kontekście pierwszych tomów, które cechuje poznawczy rozmach. Faktem jest, że poezja Hartwig nie wypowiada się na temat „drugiej strony”, wczesne tomy tematyzują zaś poznawczy postulat jej odsłonięcia. 
sku Tajemnicy. Konsekwencją takiej postawy w tomach Wolne ręce, Dwoistość, Chwila postoju było maksymalistyczne dążenie do zgłębienia wielorakich przestrzeni bytu, przejawiające się w potrzebie przekroczenia własnej jednostkowej egzystencji, w chęci zjednania się z doświadczalnym światem, w panteistycznym postrzeganiu otaczającej rzeczywistości, dochodzącym do głosu w onirycznej poetyce jukstapozycyjnego zestawiania obrazów.

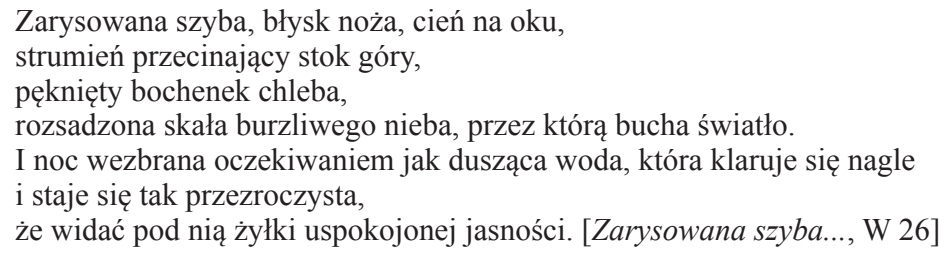

Poetyka, którą Barańczak określił mianem „wizyjności konkretu”79, ustanawia odmienną od racjonalnej perspektywę poznawczą. Poszczególne obrazy w wierszu łączy motyw ostrego przebłysku jasności, który osiąga swą kulminację w ostatnich czterech wersach, wskazując na oniryczną proweniencję doznania. Moment, w którym podmiot (wyeksplikowany pośrednio, liryk bowiem mówi jedynie o „nocy wezbranej oczekiwaniem", odnoszącym się wszak do kogoś) doświadcza stanu przeźroczystej jasności, wymaga wydobycia tego odczucia z mroków nocy i snu oraz natężenia zmysłów do tego stopnia, że materia wokół gęstnieje. A jeśli ten moment się zdarza, to nadchodzi nagle, $\mathrm{z}$ reguły o świcie lub w świetle południowego słońca, przywodząc na myśl skojarzenie z mistycznym doznaniem rzeczywistości, zakładającym pewien rodzaj intuicyjnego czy epifanijnego poznania. Konkret, materia świata, którą próbuje się rozłamać w pół, obnażyć w świetle dnia, ale również sen, stający się nie mniej ważną, może nawet ważniejszą płaszczyzną poznania. Interpretacja poetyckich snów Hartwig pozwala je widzieć w duchu Jungowskim, jako źródło mądrości archetypicznej, zbiorowej nieświadomości, miejsce ujawniania się pewnej elementarnej prawdy ${ }^{80}$. Wojciech Ligęza pisze, że Hartwig „Marzy o snach epifanicznych: by zbliżyć się do ukrytej istoty, by odnowić więź z pradawną wiedzą rodzaju ludzkiego"; podobnie treść poetyckich snów autorki Dwoistości postrzega Ryszard Przybylski ${ }^{81}$ ). Sen daje więc szansę powrotu do mitycznej harmonii prapoczątku, w aspekcie poznawczym - niweluje dysonanse rzeczywistości, rezygnując z ostrych granic na rzecz swoistej labilności obrazu.

79 S. B a r a ń c z a k (Pasja dnia. W: Przed i po. Szkice o poezji krajowej przełomu lat siedemdziesiatych i osiemdziesiatych. Londyn 1988, s. 15) rozumiał przez to posługiwanie się zdekontekstualizowanym, acz „realistycznym” obrazem w miejsce skomplikowanej metafory, który poprzez swą „fragmentaryczność i niedopowiedzenie”, zestawiony jukstapozycyjnie z innymi obrazami odwołującymi się do konkretu, tworzy wizyjną całość.

80 Zob. R. Przy by lski, To jest klasycyzm. Wstęp M. J a n i o n. Warszawa 1978. - B a$\mathrm{r}$ a ń c z a k, Tajemna wiedza snu. O roli snu w poezji Hartwig pisze S m olk a (op. cit., s. 19-24): „Owo prawdziwe przeniknięcie i połączenie antynomii, świata realnego i idealnego, widzialnego i duchowego najczęściej spełnia się we śnie. Jest to osobna sfera tej poezji, która zagarnia w siebie tyleż zamglone, niejasne, ukryte krajobrazy, co te realne, wyraziste; łączy podświadomość z wiedzą historyczną, przeczucie z mitami kultury”; a W. L i g ę z a (Poetka milczenia. „Twórczość” 1980, nr 11, s. 132) dodaje, że w poezji tej: „Przebudzenia przynoszą też wspomnienie o jakiejś wiedzy utraconej (pewnej lub złudnej), nie dającej się wysłowić w języku pojęciowym”.

${ }^{81}$ Li gę z a, op. cit., s. 132. - R. Pr z y by ls ki, op. cit., s. 69. 
Pozostaw mnie jeszcze przez chwilę w niestateczności snu.

[. . . . . . . . . . . . . . . . . . . . . .]

Bo tam nareszcie jest we mnie odnaleziona pradolina Wisły, zielona i promienna dolina Niniwy zobaczona w zachwycie.

Ziemia, której szukam i którą rozpoznaję, by pojednać się z nią, kiedy tak stoi w zmierzchu nieruchoma i wieczna. [Pozostaw mnie, O 29]

Element pierwotności może być zatem odnajdywany w zagłębieniach snu. W sytuacjach granicznych, na styku dnia i nocy, otwierają się rejony wizyjne. Rzeka ciemnych i nieracjonalnych doznań, mimo pozornie ściszonych emocji, to źródło fascynacji i jakby podskórny prąd tej poezji rezygnującej z ,solarności na rzecz telluryczności" ${ }^{2}$. Swiat realny zobaczony we fragmencie wielością oczu i punktów widzenia oraz pragnienie scalenia i szukania ładu w sferze onirycznej - to dwie dopełniające się próby przejścia w kierunku tego, co przekraczające jednostkową egzystencję i istotowe. Nieoczywiste $\mathrm{i}$ absurdalne realnie - w śnie bywa wiązane na zasadach praw naturalnych. Alogika snu pozwala na ukazanie rozległych analogii między zjawiskami pozornie bez związku. Oniryczna perspektywa staje się zatem „sposobem na rzeczywistość" ${ }^{83}$. „W sferze marzeń sennych ulega zawieszeniu zasada tożsamości" - podmiot zatraca swoją immanentność, rozwarstwia się, poczucie tożsamości ulega rozproszeniu, Ja staje się Ty, możliwe jest równoczesne bycie Innym, spełnia się zatem pragnienie przekroczenia jednostkowej perspektywy ${ }^{84}$. Funkcja estetyczna snu wydaje się w tym wypadku wynikową funkcji poznawczej, a jego wewnętrzne prawidła pozwalają na zastosowanie swobodnego toku obrazów, które mogą funkcjonować jako samodzielne fragmenty. Anna Sobolewska twierdzi za Danutą Danek, że poetyckie konstrukcje znaczeniowe znajdują się w bezpośrednim związku z zasadą tworzenia konstrukcji onirycznych ${ }^{85}$, Hartwig potwierdza tę zależność, pisząc, że sen „wynika z samorodnego ruchu wyobraźni" ${ }^{86}$. Wizyjność nie dotyka tylko przestrzeni snu, lecz wkrada się w rzeczywistość codziennego doświadczenia, m.in. dzięki wspomnianej jukstapozycji ${ }^{87}$. Obraz traci referencyjny charakter, sugerując swój wymiar znakowy. Wiele utworów przyjmuje postać uporządkowanej wizji sennej, przez co trudno określić, czy sytuacja należy do sfery onirycznej, czy do realnej - nakładają się one na siebie, sprawiają wrażenie, że konkret uwalnia się od swoich ram,

${ }^{82}$ Ko c i ub a, op. cit., s. 43.

${ }^{83}$ E. D ą b ro w s k a, „Mowa petna wahań i zapytań” - o sztuce poetyckiej Julii Hartwig. „Język Artystyczny” t. 12 (2003): Literatura kobiet, literatura kobieca, kobiecość w literaturze, s. 181.

${ }^{84}$ A. S o b o 1 e w s k a, Jak sen jest zrobiony? Poetycka materia snu. W zb.: Oniryczne tematy $i$ konwencje w literaturze polskiej XX wieku. Red. I. Glatzel, J. Smulski, A. Sobolewska. Toruń 1999, s. 23.

${ }^{85}$ Ibidem, s. 19-20. Zob. też D. D a n e k, Sztuka rozumienia. Literatura a psychoanaliza. Warszawa 1997.

${ }^{86} \mathrm{H}$ a r tw i g, Świat trzeba przefiltrować przez siebie, s. 51.

${ }^{87} \mathrm{~S}$ h e p p a rd (op. cit., s. 97) pisze: ,sporo istotnych tekstów modernistycznych stawia sobie jako problem centralny wtargnięcie »metaświata« w »pośrednią strefę doświadczenia«; zburzenie pozornie bezpiecznego, zdroworozsądkowego świata mieszczańskiego przez moce pod- lub nieludzkie, kosmiczne lub, w najlepszym razie, nie poddające się zdrowemu rozsądkowi”. Wskazuje następnie sposoby ujawniania się owych metaświatów w różnych dziedzinach sztuki modernistycznej, w prozie widzi je m.in. w odejściu od linearnego porządku, we wprowadzeniu narracji o ograniczonej perspektywie, w technikach montażu, a w malarstwie - w odejściu od tradycyjnej perspektywy trójwymiarowej. 
a sen przyjmuje kształt rzeczywistości. Względność tę wskazywał Ryszard Przybylski jako jedną z głównych cech poezji Hartwig ${ }^{88}$. W interpretacyjnym dookreśleniu owych przestrzeni o różnym statusie ontologicznym może się stać przydatna kategoria metaświata, jaką stosuje Sheppard, analizując modernistyczny zwrot W postrzeganiu rzeczywistości ${ }^{89}$. Wprowadzam ją w miejsce szerokiego pojęcia surrealizmu ${ }^{90}$, które, przywoływane przy okazji poetyki wczesnej twórczości Hartwig, budzić może liczne zastrzeżenia ${ }^{91}$. Sheppard, omawiając modernistyczne odkrycie metaświatów, gdzie zawodzą prawa fizyki Newtonowskiej, zwraca uwagę także na skutki tego odkrycia dla nowych technik literackich. U Hartwig światy możliwe, światy oniryczne, bliskie są konstrukcji metaświatów, w których trzeba zakwestionować racjonalne kategorie epistemologiczne. To wierność nie tyle szkole surrealizmu, ile przekonaniu o niejednowymiarowym aspekcie rzeczywistości. Odejście od linearności i ciągłości obserwacji oraz brak przyczynowości sprawiają, że ,klasyczne kategorie czasu i przestrzeni zmieniły się z niezależnych i obowiązujących absolutnie ram odniesienia w pojęcia zrelatywizowane do prędkości obserwowanego obiektu oraz położenia obserwatora"92. Znajduje to swoje odbicie w poezji Hartwig, gdzie, zgodnie z przytaczanym już trafnym rozpoznaniem Legeżyńskiej, rzeczywistość przedstawiona jest w subiektywnej optyce, realizującej się we właściwym jej kadrowaniu obrazu oraz w punktowym widzeniu ${ }^{93}$. Takie spojrzenie na oniryczną konwencję u Hartwig nie tylko pozwala odkryć „dziwność” i „obcość” surrealnej rzeczywistości, co podkreślał Telicki, ale także wskazuje na władze poznawcze podmiotu i jego doświadczenie świata, postrzeganego w swej złożoności ${ }^{94}$. Tę skomplikowaną naturę rzeczy, której oddanie umożliwiają sen i świadome związanie go z poezją, potwierdza w swej wypowiedzi sama autorka:

${ }^{88}$ R. Przybylski, op. cit., s. 70.

89 Surrealistyczne obrazy - jakby zaczerpnięte ze snu, które wkraczają w świat codzienności - Sh e p pard (op. cit., s. 97) uważa nadto za jeden z literackich przejawów zmieniającego się poczucia sensu rzeczywistości i wtargnięcia metaświata w zwyczajną sferę doświadczenia. Kategoria metaświata okazuje się więc mniej uwikłana w historycznoliterackie spory niż termin „surrealizm” i stara się przede wszystkim uchwycić znaczące przesunięcie w sferze statusu poznawczego rzeczywistości.

${ }^{90}$ Użyteczność zastosowania do analizy poezji Hartwig pojęcia surrealizmu szczegółowo zbadał Teli ck i (op. cit., s. 82), celowo omijając klasyczne definicje i wykorzystując jako klucz $\mathrm{w}$ interpretacji kategorię surrealizmu etnograficznego, zaczerpniętą z teorii J. C 1 if for d a. Teli c k i zaznacza: ,decyduję się mówić o surrealistyczności również w szerszym sensie, oddającym pewną dziwność i niesamowitość życia, która umyka opisowi racjonalnemu” (s. 82). Dlatego też proponuję szerszą kategorię metaświata jako nie wymagającą relatywizowania i uogólniania pojęcia surrealizmu, którego analiza nie jest przecież istotą tego artykułu.

${ }_{91}$ Autorka Błysków odżegnuje się od świadomego czerpania z dorobku surrealizmu. Jednocześnie sąd M. B ar a n ow ski ej (Surrealna wyobraźnia i poezja. Warszawa 1984, s. 146), która stwierdza, że surrealizm wyrósł z przekonania o materialistycznym statusie rzeczywistości, bez odniesień do transcendencji, podważa niejako zasadność szukania wspólnego mianownika światoodczuwania Hartwig i surrealistów.

${ }_{92}$ S h e p pard, op. cit., s. 93-94.

${ }_{93}$ L e ge ży ń sk a, Od kochanki do psalmistki..., s. 251.

${ }^{94} \mathrm{Ligęz}$ a (op. cit., s. 133) w recenzji Chwili postoju stawia taką oto diagnozę: „Światy [poezji] Julii Hartwig są hybrydami ontologicznymi. Poetka celowo komplikuje relacje między zewnętrznością a wnętrzem, miesza porządki istnienia, uruchamia jednocześnie różne płaszczyzny czasowe". 
U mnie sen odgrywa rolę jakby przygotowania do poezji.

Uczy nas, poetów, że różne rzeczy, różne czasy, różni ludzie mogą istnieć razem, w tym samym momencie i że to nie jest dziwne. Nie mówiąc o tym, że sen jest czymś bardzo tajemniczym, a sztukę pociągają tajemnice. W poezji szuka się prawdziwego sensu, który w codziennym życiu bardzo często tracimy z oczu. I kiedy wydaje nam się, że już go na dobre utraciliśmy, próbujemy go odnaleźć w jakiejś innej przestrzeni, na przykład w sztuce. Nie odnajdziemy go, co prawda, za jej pośrednictwem, ale przynajmniej cieszymy się poszukiwaniem ${ }^{95}$.

A zatem sen jako tajemnica i egzemplifikacja warstwowej struktury rzeczywistości, technika oniryczna w służbie poznawczych dążeń podmiotu. Sen zostaje zrównany z poezją w jego funkcji porządkującej i scalającej obraz świata, jak w wierszu Zona:

Oddech wszechświata był ciężki

Jeżeli coś jeszcze szło za dyktandem sztuki

to sen

Ale i on był zbłąkany [T 24]

W pierwszym okresie Hartwig odwołuje się do wizji, czerpie z intuicji „,mistycznej" (która odezwie się znów silniejszym głosem w późnej poezji autorki To wróci), buduje obszerny projekt poznawczy, wyrażający się w podmiotowym aktywizmie, oraz zawierza snom, godzącym d w o is t o ść rzeczywistości.

\section{Epifanie widzialności}

Poczynając od tomu Obcowanie, Hartwig zwraca się „ku centrum świata”, które umieszcza w jednostkowych przejawach rzeczy i zdarzeń. Forma wyrażenia owego przekonania o istnieniu świata niematerialnego i nie poddającego się jedynie racjonalnemu oglądowi ewoluuje w kierunku poezji medytacji i widzialnej rzeczywistości. Można mieć zatem wrażenie, że konwencja oniryczna, wbrew wcześniejszym prognozom krytyków, okazała się mniej płodna niż zwrot w kierunku owego nieogarnionego ,przestworu” rzeczywistości, któremu w poezji towarzyszyć będzie silniejsze eksponowanie konkretu ${ }^{96}$.

Ten etap znaczony jest przez motyw wzroku, który ma przekroczyć granice widzialności i być czymś więcej niż tylko zmysłem obejmującym rzeczywistość fizykalną, utwierdzając w „wizyjności konkretu” owo pragnienie doświadczenia granicznego. Wskazywana dotąd wielokrotnie, afirmująca względem świata rola wzroku poszerza się zatem o ,widzenie epifanijne" ${ }^{97}$, którego celem jest nie tylko widzieć, ale też „widzieć więcej”. Autorka Czułości, przyznając, że ,w zobaczeniu

95 Sztuka patrzenia. Z J. Hartwig rozmawiają K. J a n o w s k a i P. M u c har s k i., ,Tygodnik Powszechny" 2001, nr 33, s. 13.

${ }_{96} \mathrm{~W}$ ostatnim okresie w poezji Hartwig następuje wypieranie wizji sennej, rezygnacja z konwencji onirycznej na rzecz żywiołu codzienności i kontemplacji. Poetka mniej odwołuje się do nieświadomości, choć sen nadal oznacza istotne dopełnienie dnia, nie stanowi już jednakże materii, w której zanurzony jest cały poetycki dyskurs Hartwig.

${ }_{97}$ L e g e ż y ń s k a (Od kochanki do psalmistki..., s. 261) uważa, że w przypadku poezji Hartwig możemy mówić raczej o stanach przedepifanijnych. Sądzę jednak, iż samo „wejście w krąg tajemnicy", formułowanie pytań, stawianych w jej obliczu, jest przecież zbliżaniem się do niej i jej doświadczaniem. Tak też epifanię pojmuje R. N y c z (,Prywatna księga różności”. „Teksty” 1981, nr 4/5) w kontekście Miłosza twierdząc, iż „epifanie dają poczucie wymykającego się sensu” (s. 213). 
jest więcej niż samo widzenie", a mianowicie również rodzaj zrozumienia ${ }^{98}$, legitymizuje tym samym subiektywną perspektywę, mimo że w swej poezji sumiennie unika tonu konfesyjnego. ,Widzenie” staje się centralną kategorią epistemologiczną. Hartwig problematyzuje relacje ja-świat, podmiot-przedmiot, przechodząc czasem w sposób niezmiernie płynny od rejestracji i mimetycznego zadania do rzeczywistości uwewnętrznionej ${ }^{99}$. Zarazem zmysł wzroku, poprzez który dokonuje się afirmacja widzialnego świata, staje się jednocześnie pomostem w kierunku transcendencji. Niezmiernie istotne okazuje się to sprzęgnięcie władzy podmiotu z możliwością odsłonięcia istoty rzeczy. Podmiot bowiem ujawnia, używając określenia Bielik-Robson, swoją ,moc afirmującą”, która otwiera drogę do zobaczenia głębi rzeczywistości. Daje temu wyraz wiersz Zraniony, którego tytuł wskazuje już na ważny aspekt stosunku podmiotu do doświadczanego świata:

O lato pokaż mi swój drugi brzeg
mnie która kocham cię miłością czystą
pokaż mi brzeg swój bezdrzewny bezskalny
bym uwierzyła bym się nauczyła
widzieć co nie istnieje być tam gdzie mnie nie ma [Cz 12]

Widzenie wiąże się z wiarą i transgresją, będąc procesem poznania wspartym na uwewnętrznieniu naoczności. Poprzedza je jednak „miłość czysta”, która stanowi przecież fundacyjny gest dostrzegania dobra, afirmacji, pozwalający wykroczyć poza to, co fizykalne i cielesne. Autorka Innej nowoczesności dowodzi, że epifania nowoczesna zawsze jest ukazana w jednostkowym akcie widzenia, przypominając biblijną egzegezę ,widzenia dobra” w kontekście woli uczestnictwa. Hartwig, powołując się na miłość jako warunek poznania, tym samym wyraża niejako ,romantyczną wiarę w prze mianę percepcj i” ${ }^{100}$, o której Charles Taylor powiada:

W rzeczywistości pojęcie przekształcenia naszej postawy wobec świata, kiedy to zmienia się nasz obraz rzeczywistości, tradycyjnie łączono z pojęciem łaski. Augustyn utrzymuje, iż w relacji z Bogiem miłość musi poprzedzać wiedzę. Dzięki właściwie ukierunkowanej miłości to, co w przeciwnym razie jest ukryte, staje się oczywiste. Nowością jest tutaj współczesne pojmowanie pozycji i mocy wyobraźni twórczej. Stanowi ono teraz integralny składnik dobra

${ }^{98}$ Sztuka widzenia. Z J. Hartwig rozmawia G. D r a b i k. Na stronie: www.dziennik.com/www/ dziennik/kult/archiwum/07-12-02. Data dostępu: 14 V 2007.

${ }^{99} \mathrm{H}$ a r t w i g, powołując się na słowa A. Béguina, tak oto określa zamiary poetyckie: ,dążeniem poety jest odnalezienie jedności umysłu i świata. [...] Dążenie do uzyskania jedności prowadzi ku rejonom, gdzie »ja« zatraca się na korzyść dostrzeganej w sobie obecności uwewnętrznionego świata”, i dopełnia tę refleksję własną konkluzją: „To we mnie czy p o za mną jest częstym pytaniem, które powraca w moich wierszach” (T. F e r e n c, Z. J a n k o w s k i, Julia Hartwig. „Topos” 1997, nr 4, s. 4).

${ }^{100} \mathrm{~A}$. B i e l i k - R o b s o n (Wstęp. My romantycy-źródta romantycznego modernizmu Charlesa Taylora. W: Ch. Ta y 1 o r, Źródła podmiotowości. Narodziny tożsamości nowoczesnej. Przeł. M. Gru s z c zyń sk i [i in.]. Oprac. T. G a d a c z. Warszawa 2001, s. XLIX) pisze: „Potęga widzenia jako władzy dopełniającej sferę ontologii - sferę tego, co samo w sobie pozostaje obojętne na kwestię dobra i zła [...] - to wątek obecny w duchowości judeochrześcijańskiej od jej zarania, choć zarazem od wieków pozostający w cieniu dominującej wizji greckiej, która nadaje dobru wyraźną sankcję metafizyczną". 
rzeczy, a więc także przekształcenia naszej postawy oraz naszego światopoglądu, i ułatwia ustalenie prawdy, jaką odkrywa ${ }^{101}$.

W utworze Mgnienie rozwija Hartwig poetycką relację między widzeniem miłością jako afirmacją a priori, a epifanią. W „dalekowidzeniu” dane nam jest przeczucie zbliżenia się choć na moment do Tajemnicy i pochwycenia świata, który objawia się znów „miłośnie zmniejszony / i dostępny obcowaniu”:

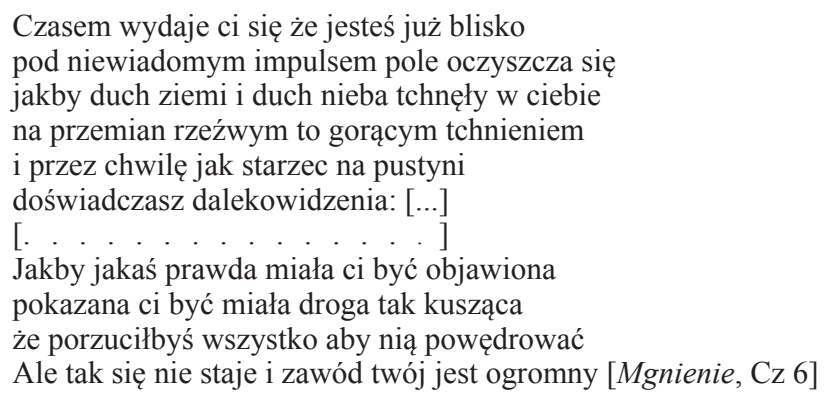

W tym sensie podmiotowa perspektywa „widzenia dobra” determinuje afirmację bytu. Hartwig ujawnia inklinacje romantyczne swojego poetyckiego światopoglądu, unikając prób wyraźnego wiązania jej z duchem klasycyzmu. Romantyczne z natury jest przecież tchnienie „niewiadomego impulsu [...]”, „ducha ziemi [...]" - połączone z figurą oczyszczenia sprawiają, że ma się poczucie obcowania z jakąś ponadludzką siłą, która stwarza się, ale i jest stwarzana przez podmiot wiersza. Poetka jednak tę intuicję, przebłysk bierze w klamrę niejednoznaczności i przypuszczenia; owe „wydaje ci się”, ,jakby” wskazują na fakt, iż moment ten wymyka się ścisłym określeniom, zanim zdąży się zmaterializować w swej istocie i zostać poddany refleksji. Ale ma się wrażenie, że taka jest natura epifanii: fantasmagorycznej i nie podlegającej racjonalizacji, intuicyjnej i rozpraszającej się, zanim świadomość zdoła ją pochwycić. Przede wszystkim „ta chwila”, jako określenie „dalekowidzenia”, zawsze przychodzi niespodziewanie, niejako bez wsparcia ze strony świadomości podmiotu, trafiając się podczas codziennych zdarzeń czy momentów zatrzymania uwagi - jak kontemplacja pejzażu. Podmiot zarazem ma przeczucie, że dostępuje nie określonej bliżej, niepowtarzalnej granicy, kiedy to, co najistotniejsze, ma mu zostać objawione. Próbuje to doznanie zwerbalizować, rozpoznać, lecz zatrzymuje się u progu niewyrażalności i niepochwytności przeżycia. Zespolenie władzy oka i serca, widoczne w wielu utworach Hartwig, wskazuje na jeszcze jedną implikację: świeżość spojrzenia, która warunkuje „trwanie w odświętności”, czyli dostrzeganie sakralnego wymiaru świata i wyjątkowości jednostkowego aspektu rzeczy, możliwa jest dzięki woli i empatii.

\author{
Więc już codzienne ci to i zwyczajne \\ co wczoraj jeszcze było zachwytem \\ i poczuciem że niezasłużone? \\ Oko które przywykasz \\ serce co się ścierasz zbyt szybko jak porowaty kamień \\ uczcie się trwać na co dzień w odświętności
}

${ }^{101}$ Ta y 1 o r, Źródła podmiotowości, s. 825. Autor twierdzi więc, że zmieniona postawa wobec podmiotowości i świata pozwala nie tyle rozpoznać ukryte dobra, ile je urzeczywistnić. 
Jezioro nad którym chyli się ta góra przebita strzałą mgły jest przecież równie piękne dziś jak wczoraj Słońce ślizga się po nim jak uczniak zjeżdżający wzdłuż poręczy schodów [Co wczoraj jeszcze, O 77]

Epifania we wczesnej poezji autorki Zobaczonego, odwołująca się do szerokiej, często onirycznej wizji, swego źródła szuka następnie w intensywnym obcowaniu z realną rzeczywistością, stając się ważną formą kontaktu z esencjalnym wymiarem świata ${ }^{102}$. Jak to ujmuje Ryszard Nycz, w szerokim sensie epifanii zawiera się sposób poznania (,,stan umysłu”) i jego rezultat (,„»rewelacja« jakiegoś fragmentu czy aspektu rzeczywistości”" ${ }^{103}$. To często moment przeczucia nieosiągalnej prawdy, wejście w przedsionek Tajemnicy - w twórczości Hartwig zawsze kończący się dotarciem do epistemologicznego kresu. Olśnienie pozostaje więc tylko b łys k i e m, ulotnym i nieuchwytnym, ,tą chwilą”, kiedy wszystko staje się jasne, by zaraz znów dać się porwać przez nurt egzystencji, pozostawiając żal i poczucie zawodu. W utworze Mgnienie dalej otrzymujemy właśnie taką oto diagnozę: „Ten moment jest tak krótki że wprost nie ma trwania" (Cz 6). Najwyższa intensywność przeżycia to chwila napięcia trwania roztopionego w swoistym bezczasie. Centralnym punktem wiersza wydaje się moment zatrzymania, olśnienia świadomości. Jego treścią staje się doznanie piękna lub spostrzeżenie prawd ogólnych, elementarnych w sytuacjach zwykłych i jednostkowych. Chwila taka bywa wyrwana $\mathrm{z}$ biegu czasu, zatrzymana $\mathrm{w}$ momencie dziania się (Noca w Bellagio, T 27), przybiera w poetyckim ujęciu postać rozbłyskującego obrazu i niesie informację, o której Przybylski pisze, że „,chociaż dotyczy pojedynczego człowieka, mówi zawsze o doświadczeniu rodzaju. Jest poszczególna i uniwersalna. Brzmi jak wystrzał"104, wskazując, iż Hartwig dokonuje egzystencjalnego uogólnienia jedynie opierając się na jednostkowym doświadczeniu. Rozpoznanie to pokrywa się z założeniem autorki Bez pożegnania, która w napięciu między tym, co indywidualne, a tym, co ogólnoludzkie, widzi wartość poezji.

Ważną sprawą dla poezji jest wybór między tym, co ogólne i co szczególne. I ile odsłonić się da w poezji, i zasłonić zarazem, z naszych dramatów osobistych, tak, by zapisując naszą osobność, zarazem łączyć się z innymi w tym, co najbardziej człowiecze ${ }^{105}$.

Tę poetycką drogę autorka Błysków przebywa, wychodząc „,na ogół od jednej sytuacji, obrazu, spostrzeżenia, by nadać im ruch w kierunku pamięci, przyszłości, nieokreśloności, metafizycznej udręki lub ekstazy" ${ }^{106}$. Realizuje się ona także w doświadczeniu epifanii, która rodzi się jako przeżycie subiektywne, jednostkowe, krocząc przy tym w kierunku diagnozy egzystencjalnej.

Epifanijne doznanie piękna pozwala umieścić je w przestrzeni sacrum, która

${ }^{102}$ Zarówno dla Nycza, jak i dla Taylora dyskurs epifaniczny to kluczowe osiągnięcie późnego modernizmu.

${ }^{103}$ R. N y c z, Literatura jako trop rzeczywistości. Poetyka epifanii w nowoczesnej literaturze polskiej. Kraków 2001, s. 11-12.

${ }^{104}$ R. P r z y b y 1 s k i, op. cit., s. 64.

${ }^{105}$ J. H a r t w i g, Kilka niechętnych uwag o pisaniu. „Topos” 1997, nr 4, s. 7.

${ }^{106}$ A. S z y m a ń s k a, Patrzeć aż do bólu. O szukaniu i znajdowaniu w poematach proza Julii Hartwig. „Topos” 2004, nr 3/4, s. 58. 
w poezji Hartwig obejmuje całą rzeczywistość widzialną (w znaczeniu religijnym „epifania” jest przecież uobecnieniem świętości). Świat nie ulega sekularyzacji, przeciwnie - widoczne jest dążenie do utrzymania wspomnianej kategorii. Hull czyni w tej kwestii istotne spostrzeżenie:

Dar rzeczywistości sam w sobie traktuje jako sferę sacrum, a nie przejaw sytuującej się poza nią idei. Można by zaryzykować tezę, wyprowadzając ją ze sposobu poetyckiego obrazowania rzeczywistości, że w swoim ujęciu bliska jest teoriom panteistycznym, w wersji monistycznej Spinozy. Akcent pada nie na akt stwórczej kreacji, lecz na substancjonalny wymiar rzeczywistości, zakładający też, że natura nie może istnieć poza Bogiem ${ }^{107}$.

Sakralizacja przestrzeni widzialnej wzbogaca jej sferę o przestrzeń ukrytych znaczeń poprzez odwołanie do topiki biblijnej czy symboliki kosmogonicznej. Oglądany pejzaż staje się metonimią wyższego porządku:
Pośpiech brzóz biegnących na spotkanie maja
w zielonej mgiełce oddechu
bo chcą być pierwsze pierwsze zawsze pierwsze
w wiosennym wyścigu zieleni
Witają je z dołu okrągłe okrzyki zawilców
i kruche karuzele tarnin
Wisła strzępiona wiatrem próbuje wzbić się w górę
przyciągana szarym magnesem nieba
$\mathrm{Za}$ oraczem mewy wiślane
horyzont krąg zatacza jak pętla zaskrońca
który trzymając własny ogon w pysku
zamyka tę małą nieskończoność [Pośpiech, Cz 33]

Hartwig patrzy na pejzaż przez pryzmat fundującego go ładu. Między dołem a górą odbywa się ruch świata, Wisła „dostępuje nieba”, z „dołu okrągłe okrzyki zawilców" witają biegnące ku górze brzozy. Ostatecznie obraz wychyla się w kierunku transcendencji poprzez analogię między linią horyzontu a kołem kosmicznym symbolizowanym przez węża $\mathrm{z}$,ogonem w pysku”. Widok nigdy nie jest statyczny, przemieniając się w rozwijaną w płaszczyźnie wertykalnej wizję. Obserwowany skrawek świata okazuje się więc miniaturą doskonałej pełni, harmonii materii i kompletności wiecznego ruchu świata. Hartwig jednocześnie uzwyczajnia ową symbolikę, zamiast węża wprowadzając pospolitego zaskrońca. Zabieg ten ma na celu umieszczenie wymiaru kosmicznego w przestrzeni codziennej, wpisanie sfery sacrum w doskonałość widzialnej rzeczywistości.

Epifania nowoczesna staje się zatem ,»miejscem《 spotkania z rzeczywistością", ale również z tym, co inne i niewyrażalne. Nycz rozróżnił jej dwa podstawowe rodzaje - epifanię romantyczną, która spełnia się w „,prześwieceniu wiecznego w przemijającym”, oraz modernistyczną, która odwrotnie - „p o le g a n a uwiecznianiu tego, co przemijają ce" 108 . Dzieło romantyczne szuka więc Tajemnicy w transcendentnym porządku, a dzieło nowoczesne - w niepowtarzalnej rzeczywistości ${ }^{109}$. Momenty nagłego wejrzenia w Tajemnicę, poszerzenia jaźni, zniesienia granicy między własną suwerennością a pochłaniającym żywiołem tego, co nas otacza, wiążą się w tej poezji ze stanem olśnienia, z uwewnętrznionym,

\footnotetext{
${ }^{107} \mathrm{H} \mathrm{u} 11$, Arkadyjskie pejzaże Julii Hartwig, s. 168.

${ }^{108} \mathrm{~N}$ y c z, Literatura jako trop rzeczywistości, s. 12, 47.

${ }^{109}$ Ibidem, s. 88-90.
} 
kontemplacyjnym oglądem świata, niekoniecznie zaś z uobecnieniem Boga. Zachwyt czerpany z potęgi wzroku jest zrównany - pod względem mocy objawienia metafizycznej pełni - z wiarą.

Takim cię pamiętam i takim chcę zapamiętać

morze znajomej zatoki

To co jest we mnie w takiej chwili

mierzy się z tobą i jest jak ty rozległe

oczy cieszą się grą blasków

wzrok ślizga się od horyzontu do horyzontu

ciało staje się lżejsze a stopy jakby same szły po falach

i to co mogłaby sprawić wiara - tu dzieje się za sprawą zachwycenia

(Sponiewierane przypomina sobie dawna godnośćc, Cz 35)

Doznanie wizualne bywa zatem tak silne, że prowadzi do zatracenia poczucia własnej cielesności. Ten dar kontemplacji, umożliwiający zjednoczenie z rzeczywistością, wymaga jednakże umiejętności wykroczenia poza ,ja”, o której Hartwig pisała wielokrotnie, iż jest ,wielkim darem nieba w ogóle, jeżeli człowiek nie za wiele myśli o sobie” ${ }^{110}$. „Ja” zwrócone do świata, ,ja”, którego codziennym przykazaniem jest umiejętność ,życia w odświętności”, świeżego oglądu zjawisk i które „epifanijne dotknięcie piękna" 111 traktuje jako wynik afirmacji rzeczywistości w jej codziennych przejawach. Wydaje się, że epifanię podobnie pojmował Miłosz w Wypisach z ksiag użytecznych:

Epifania przerywa więc codzienny upływ czasu i wkracza jako jedna chwila uprzywilejowana, w której następuje intuicyjny uchwyt głębszej, bardziej esencjalnej rzeczywistości zawartej w rzeczach czy osobach.

I dalej:

Może [...] oznaczać samą otwartość zmysłów wobec rzeczywistości. Oczy zdają się być tutaj organem uprzywilejowanym, choć może to nastąpić dzięki słuchowi, dotykowi czy smakowi ${ }^{112}$.

Ten zwrot $\mathrm{w}$ kierunku rozumienia epifanii w sensie Joyce'owskim ${ }^{113}$ : jako momentu olśnienia ważnego dla świadomości podmiotu, wspólny jest - jak można wnioskować - dla Hartwig i Miłosza. W takiej epifanii podmiot przeżywa nie tylko istnienie świata, ale i jedność $\mathrm{z}$ nim. Nagłe błyski widzenia rodzą się więc $\mathrm{w}$ sprzęgnięciu z wewnętrzną dyspozycją podmiotu. „Nowa epifania zachowuje najważniejsze cechy starej: objawia świat jako jedną całość i daje jednostce silne poczucie przynależności. Przy tym jednak jest ona indywidualna, a to znaczy, że współtworzy ona to, co odkrywa" - konstatuje Taylor w rozważaniach na temat

${ }^{110}$ Sztuka widzenia, loc. cit.

${ }^{111}$ M. C z e r m iń s k a, Żyjąc zyskujemy życie. O późnych wierszach Julii Hartwig. W: Księga Janion. Oprac. Z. M a j c hrow s k i, S. R o s i e k. Gdańsk 2007, s. 209.

${ }^{112}$ Cz. Miło s z, Wypisy z ksiag użytecznych. Kraków 1994, s. 17-20.

${ }^{113}$ W literackich ujęciach epifanii szczególne miejsce zajmują dwa, mianowicie to przedstawione przez M. Prousta w powieści $W$ stronę Swanna, gdzie słynna scena jedzenia magdalenki wywołuje reminiscencję z dzieciństwa, oraz nowy wymiar modernistycznej epifanii, nadany jej przez J. J o y c e'a w Portrecie artysty z czasów młodości. W tym utworze pojawia się epifania, której źródłem mogą być powszednie zdarzenia, a także - podobnie jak u Prousta - jakiś detal, drobny przedmiot. 
modernistycznych objawień i opisuje je jako wizję, która ,pomaga dopełnić to, co jednocześnie odsłania" ${ }^{114}$.

\section{Uwewnętrznienie naoczności}

Legeżyńska stwierdziła, iż w poezji Hartwig metafizyka nie jest przestrzenią jawnie tematyzowaną, a ukazujące się przesłanki jej istnienia są wpisane w konkret codzienności i muszą być odczytywane pośrednio ${ }^{115}$. Chociaż uwaga ta wydaje się słuszna, trudno zgodzić się z sądem badaczki, jakoby w przeciwieństwie do Miłosza, w którego poezji metafizyka odgrywa rolę konstytutywną, Hartwig traktowała ją pobocznie. Sądzę bowiem, że niebezpośredni sposób wyrażania to wynik przemyślanej postawy światopoglądowej, w której dopiero zwrot ku temu, co realne, otwiera nam drogę do głębszej prawdy o świecie. Hartwig tym samym dostrzega poznawczą funkcję poezji, pozwalającą spojrzeć zarówno „na” rzeczywistość, jak i „poprzez” nią, wskazując jednocześnie, iż jest to rodzaj poznania intuicyjnego ${ }^{116}$.

Rzeczywistość widzialna stanowiła dla mnie zawsze stały punkt odniesienia. Przy całej jego ułomności nie ma wszak świata doskonalszego niż ten, który istnieje. Ale nie ogranicza się on przecież do swojej formy. Prawda o nim, jego dostępny nam obraz, przenosi nas zarazem w jakiś przedziwny sposób w rejon niewidzialnego. Poprzez kontakt z nim dokonuje się przemiana rzeczywistości zewnętrznej w wewnętrzną. Doświadczenie rzeczywistości staje się w ten sposób rodzajem doświadczenia transcendentnego. Nie przeczę, że można by ten stosunek do świata uznać za rodzaj mistyki rzeczywistości, nie boję się tego. Wierzę, że można tak opisać rzecz, widok, sytuację, by czytelnik zrozumiał, że mają one jeszcze inne, ukryte sensy. Poezja spotyka się tu niespodziewanie z opisem uprawianym przez fenomenologów [... $]^{117}$.

Każdorazowy ogląd rzeczywistości wykracza zatem poza to, co widzialne, i próbuje dotrzeć do rdzenia rzeczywistości, zmierzając do fenomenologicznego opisu. „Poezja jest więc egzystencjalnym dwuskokiem - w przyziemność naoczności i metafizykę jednocześnie" - jak trafnie podsumowała tę autorską deklarację Katarzyna Bieńkowska ${ }^{118}$. Chciałabym więc interpretować jednostkowe zdarzenia liryczne, osadzone w poetyce konkretu, jako warunek konieczny owej metafizyki. W tym sensie twórczość Hartwig koresponduje z myślą Adama Zagajewskiego, ujętą w eseju pt. W cudzym pięknie, który stwierdza: „Tylko rzeczy duchowe są naprawdę zajmujące. Ale prawie nie można o nich mówić - bo są przezroczyste jak muślin. Można mówić tylko o ludziach i rzeczach - tak, żeby rzucały cień" ${ }^{119}$. Poezja stanowi zatem zapis doświadczania świata i próbę scalenia różnych przestrzeni (snu i sfery widzialnego, sfery imaginatywnej i intuicyjnego poznania). Przemiana rzeczywistości zewnętrznej w wewnętrzną i dostęp do jej ukrytego wymiaru wskazują, że widzenie nigdy nie istnieje w stanie czystym, jako obiektywny fakt spostrzeżeniowy, natomiast jest zawsze funkcją interpretującej świadomości.

${ }^{114}$ A. B i e lik - R o b s o n, Romantyczne dopetnienie. Komentarz do epifanii nowoczesnej Charlesa Taylora. „Res Publica Nowa” 1998, nr 7/8, s. 29.

${ }^{115}$ L e g e ż y ń s k a, Od kochanki do psalmistki..., s. 255.

116 J. H a r t w i g, Stowo od Autorki. WW 6.

${ }^{117}$ Ibidem.

${ }^{118}$ K. B i e ń k o w s k a, Trwać w odświętności. „Nowe Książki” 2000, nr 11, s. 48.

${ }^{119}$ A. Z a g a j e w s ki, W cudzym pięknie. Kraków 2007, s. 220. 
Błąkać się w poszukiwaniu

Kilometrami milami sunąć przez autostrady

przecinając górskie szczyty pustynie rzeki

Jechać pędzić gnać do celu

który rozpływa się jak mgła i nagle stajesz nad przepaścią

albo nad urwiskiem kamieniołomu albo nad śmietniskiem

Cel biegnie przed tobą jak zwodniczy brzęczek jak wabiący ptak

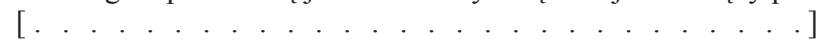

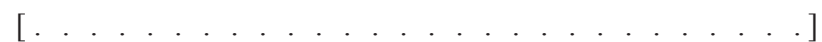

Przenieść ten pościg w głąb siebie powtórzyć tam obraz świata [Poszukiwanie, O 12]

Ostatni wers uważam za niezwykle istotny dla zrozumienia poetyckiego światopoglądu Hartwig, mówi on o potrzebie poszukiwania skierowanego do wewnątrz ${ }^{120}$. Podmiot wkłada wewnętrzny trud w zbudowanie obrazu rzeczywistości i utwierdzenie się w jego rozmyślnej strukturze ${ }^{121}$. To dzięki transformacji twórczej tego podmiotu świat zewnętrzny przechodzi w wewnętrzny i odsłania swe ukryte oblicze. Rzecz komplikuje się jeszcze bardziej na drodze poetyckiego utrwalenia doświadczenia świata, w poezji modernistycznej proces poznawczy wikła w podwójną zależność zarówno rzeczywistość zewnętrzną, jak i wewnętrzną. W werbalizacji artystycznej przedmiot opisu może przyjmować pewne cechy rzeczywistości wewnętrznej, poprzez którą jest przedstawiany, tym samym uzależnia się od „medium, w którym się »ucieleśnia «" 122 . Takie wydaje się też w swym sednie Taylorowskie wyrażenie, gdzie naturę możemy poznać tylko dzięki wysłowieniu tego, co znajdujemy w sobie.

Pokazać niewidzialne... Pokazać zatem nas samych. Naszą świadomość, która dosięgając ledwie fragmentu rzeczywistości, tęskni za całością. Podąża za głosem, który słyszą zapewne wszyscy, choć nie zawsze przydają mu wagi. Nie każdy bowiem chce oglądać od wewnątrz, co z zewnątrz oglądał. Mimo że przeczuwa istnienie światów innych od tego, który uważa się za jedyny.

- pisze Ryszard K. Przybylski ${ }^{123}$. Jest to zatem doświadczanie siebie i doświadczanie świata, zmierzające do samopoznania. Człowiek niejednokrotnie staje nad metaforyczną otchłanią, która budzi w nim lęk. Jak się okazuje, wgląd w istotę rzeczy nie przychodzi bowiem z zewnątrz. Uchylić rąbka Tajemnicy można na drodze wewnętrznego wysiłku, realizując wezwanie, by „powtórzyć w sobie obraz świata". Hartwig wie, że jedynie chwycenie się rzeczywistości daje oparcie w Bycie.

${ }^{120}$ A. B i elik-R obs o n we wnikliwym Wstępie do Źródeł podmiotowości Ta y lor a (s. XXII) pisze: „Obrona »wewnętrznych« praw podmiotowości do harmonizowania napięć, które w porządku świata odczarowanego wydają się nie do rozwiązania, to jeden z bardziej oryginalnych i trwałych rysów koncepcji Taylora”. W koncepcji tej podmiot okazuje się więc owym „brakującym centrum", które stawia opór siłom fragmentaryzacji.

${ }^{121}$ Stąd tak często badacze podkreślają znaczenie podmiotowego gestu w poezji Hartwig, zmierzającego do tego, „by uczynić świat domem” - zob. W. K u d y b a, Bycie i dom (o wierszu „Miejsca” J. Hartwig). "Topos” 2004, nr 3/4. Hull (Arkadyjskie pejzaże Julii Hartwig, s. 169-170) w rozszerzeniu horyzontu świadomości, interpretowanym w duchu Heideggerowskim, widzi „stałą dyspozycję zadomowienia w otwartej przestrzeni świata".

${ }^{122}$ Zob. N y c z, Literatura jako trop rzeczywistości, s. 8-9.

${ }^{123}$ R. K. P r z y b y $1 \mathrm{~s}$ k i, Pokazać niewidzialne. W: Wszystko inne. Szkice o literaturze, sztuce i kulturze współczesnej. Poznań 1994, s. 134. 
Pojona od dzieciństwa mlekiem wdzięczności wiele trudu poświęcam by nie mówić hymnami by nie roztopić się w odświętnym blasku jeziora po którym płynący łabędź zostawia za sobą ślad godny żeglownego statku

[. . . . . . . . . . . . ]

Gdy tak stoi zapatrzona w blask na wodzie przelatująca nad jej głową mewa śmieszka wzbija się właśnie w górę ku niebu gdzie też jest jezioro jezioro jezioro [Zapatrzona, J 16]

Doświadczenie istnienia łączy się z doznaniem piękna powszedniego świata. Przeżywany w ekstatycznym doznaniu konkret odsłania swój najgłębszy sens, który spełnia się w owym ,jest”, stając się znakiem istoty rzeczy. Poprzez epifaniczny blask jeziora, będący swoistym samoobjawieniem rzeczywistości, otwiera się perspektywa transcendencji. „Zapatrzona” wpatruje się w blask na wodzie i jego odbicie na nieboskłonie, mewa, wzlatując w niebo, szuka w nim również powtórzonego obrazu jeziora. Autorka Czułości wykorzystuje figurę lustrzanego odbicia, wskazuje na metaforyczne zjawisko podwójnego odsyłania, gdyż niebo przegląda się w wodzie, a woda w niebie, dając wrażenie, iż materia dwóch sfer znów zostaje połączona w harmonijnym trwaniu świata. Blask jeziora nabiera niejako symboliki claritas, to niezwykłe doświadczenie z a p a tr z e n i a nosi w sobie znamiona doświadczenia metafizycznego. Zatem rzeczywistość, która ,jest”, a więc „istnieje obiektywnie", u swej podstawy ma wymiar metafizyczny. To przekonanie o jej „niezależnym od percepcyjno-poznawczo-językowych władz podmiotu” 124 byciu, któremu nigdy nie zaprzeczy Hartwig, pozwala umieścić tę poetkę w obiektywistycznym nurcie literatury, wyróżnionym przez Nycza. Jednak próba obiektywizacji poznania nigdy do końca nie zatrze stygmatu świadomości jednostkowej.

Edward Balcerzan twierdzi, że pojęcia takie jak ,niewyobrażalne”, ,niepoznawalne” czy „nieprzekładalne” ,są powiadomieniami o aktywności duchowej człowieka, kończącej się, co prawda, porażką (epistemologiczną, imaginacyjną, translatorską, autorską), ale jest to porażka honorowa, bo uwarunkowana okolicznościami, na które nie mamy wpływu” ${ }^{125}$. Świadomość natrafienia na „mur”, „urwisko kamieniołomu" wyraża się coraz dobitniej w późnych tomach poetki: Bez pożegnania, Nie ma odpowiedzi, To wróci, w których założenie o „,niepoznawalności” świata nie jest wszak równoznaczne z rezygnacją ze stawiania mu pytań ${ }^{126}$. Autorka Blysków doszła bowiem do tego momentu, w którym wie, że „nie ma odpowiedzi” - w tym punkcie „myślenie dochodzi do pewnego kresu, do pewnej granicy, której się nie da przekroczyć" ${ }^{127}$. O owym kresie poznawczym i kresie naszego

${ }^{124} \mathrm{~N}$ y c z, Literatura jako trop rzeczywistości, s. 11. W analizowanych przez tego badacza tekstach to obiektywistyczne założenie jest podstawą epifanicznego dyskursu.

${ }^{125} \mathrm{E}$. B a $1 \mathrm{c}$ e r z a n, Niewyrażalne czy nie wyrażone? W zb.: Literatura wobec niewyrażalnego, s. 19.

${ }^{126}$ Zob. Sztuka widzenia, loc. cit.

${ }^{127}$ „, Innego końca świata nie będzie”. Z B. Skargą rozmawiają K. J a n o w s k a i P. Muc h a r s ki. Kraków 2007, s. 312. 
istnienia, które przecież w tej poezji zostają ze sobą zrównane, ponieważ nigdy nie wstępuje ona za granicę śmierci, „tam, gdzie nie sięga już konwencja rzeźbiarza” (Nagrobek, O 102), coraz częściej Hartwig mówi wprost. Doniosłe wydaje się podkreślenie rangi tytułów poszczególnych tomów autorki Bez pożegnania, które zawsze okazują się znaczące. Na temat ważnego zbioru Nie ma odpowiedzi, w którym jawniej podnoszona jest refleksja nad eschatologią i metafizyką, poetka pisze:

Zawsze pilnuję, żeby tytuły moich zbiorków mówiły naprawdę o tym, co jest w środku. [...] Natomiast tytuł Nie ma odpowiedzi jest dla mnie bardzo jasny. Mianowicie wszystko, o co pytam w tym tomie, a pytam o wiele rzeczy, to są pytania, na które odpowiedzi być nie może. Dotyczą tak krańcowych sytuacji ludzkich, że wytłumaczenie ich albo jest płaskie, a wtedy nie ma po co odpowiadać, bo ta odpowiedź się nie liczy, albo trzeba sobie powiedzieć: nie wiem. To nie znaczy, że nie ma odpowiedzi, bo ona może gdzieś tam jest, ale dotyczy - muszę tu użyć słowa, które jest zbyt nadużywane - metafizyki ${ }^{128}$.

Poznawcze ograniczenie nie wywołuje już wewnętrznego rozdarcia, natomiast przynosi pogodzenie się $\mathrm{z}$ niepewnym losem i podtrzymuje wiarę $\mathrm{w}$ istnienie „drugiej strony”. Świadomość ta, właściwa wielkim filozofom i poetom, nie rości sobie prawa do Prawd i budowania Całości. Hartwig niejednokrotnie trafia na ów kres, maksymalistyczny pęd prowadzi zawsze na granicę niepoznawalnego. Wynikiem epistemologicznej nieprzejrzystości staje się przeświadczenie, że „niczego nie da się uporządkować” (N 92) oraz że można tylko, parafrazując jeden z „błysków", zbliżać się i oddalać, nigdy nie pisząc o najważniejszym (B 37).

[...] Ten, kto widział wielokrotnie śmierć, wie o niej nie więcej niż ten, co spotkał się z nią po raz pierwszy.

Im mniej jest natury, tym bardziej chcemy się w niej schować. Zaniemówię i tylko sękatą laską odpowiadać będę na pytania, wskazując to na niebo, to na ziemię. [Lata, C 32]

- dodaje poetka, podkreślając niewyrażalność spraw ostatecznych i fakt, że milczenie bywa wymowniejsze niż nadużywanie słów.

Podmiot tych wierszy staje więc w obliczu tego, co niewyrażalne a jednocześnie konstytutywne dla istnienia.

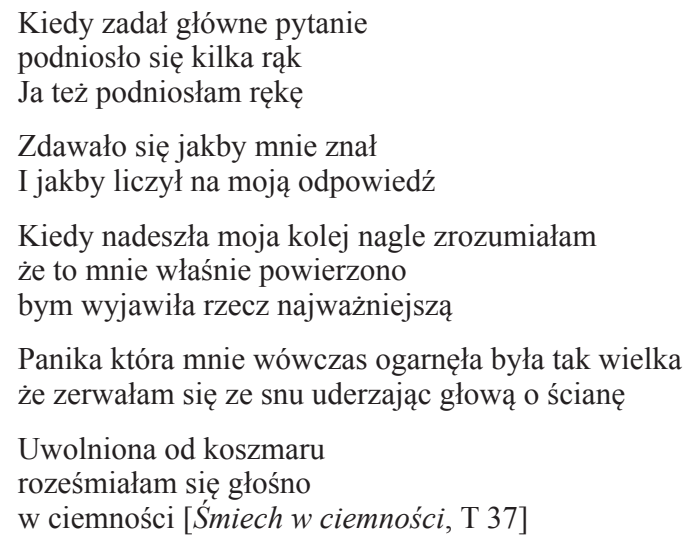

Senna wizja, w której człowiek zostaje obarczony odpowiedzialnością za

${ }^{128}$ Sztuka widzenia, loc. cit. 
wypowiedzenie ,rzeczy najważniejszej”, napawa lękiem, wiedza ta bowiem przekracza perspektywę ludzką. Mimo wszystko wydaje się, iż zza rzeczywistości nie przeziera pustka, nicość, ale wynurza się z owej rzeczywistości tajemnica, niewyobrażalne.

Pytania metafizyczne rodzi hiatus między bytem jednostkowym a całością bytu, między ciągłością a nieciągłością, między bytem rozumianym gatunkowo a jednostkowo, między tym, że jestem i że zaraz mnie nie będzie. A także - pragnienie przeniknięcia idei (istoty) świata, poszukiwania sposobów poznania pewnego, ostatecznego [...]. Pytania metafizyczne to właśnie takie, na które nie ma - nie może być - odpowiedzi. Albo są niejednoznaczne, albo stale na nowo ponawiane ${ }^{129}$.

Motyw pożegnania i przemijania, właściwy Hartwig od debiutu, w jej późnej poezji coraz dobitniej dochodzi do głosu, eksponując napięcie między chwilowością istnienia a rysującą się perspektywą kresu. W tomie Bez pożegnania ( $n b$. w największej mierze spośród wszystkich zbiorów wierszy Hartwig operującym biograficznym konkretem) ostatni utwór Dowód na istnienie dopełnia ów poetycki świat słowami:

\author{
Wszystko pogubiłam \\ nie ma już nic \\ miejsca straciły swoje miejsce \\ Więc nic? \\ Jednak po zagubieniu \\ jednak po oczyszczeniu \\ zostaje \\ niewyobrażalne \\ i komuś czy czemuś \\ o tym wiadomo [BP 89] ${ }^{130}$
}

Na fundamentalne pytanie, wyrażone w najkrótszej z możliwych formuł: „,czy zatem nic?", Hartwig odpowiada zgodnie z Leibnizowską myślą, a odpowiedź ta staje się łącznikiem jednostkowej egzystencji z metafizyką, wskazując, że poza sferą realnego istnienia „zostaje niewyobrażalne”. Poetka przekracza granicę między tym, co indywidualne (i czytane biograficznie), a tym, co ogólne. Wiersz, który mówi o zatracie fizykalnego aspektu świata, o uciekającej pamięci, zacierającej się tożsamości i znikającej prywatnej ,mapie” egzystencji, wprowadza jednocześnie pewność istnienia jakiejś wyższej świadomości, gdyż bierze w klamrę transcendencji naszą egzystencję znaczoną utratą. Afirmacja świata w poezji Hartwig nie znosi wiedzy o tragizmie egzystencji i jej przemijającej formie, lecz wspiera się na tym, co niewyobrażalne, na tym, co stanowi „dowód na istnienie”. „Niewyobrażalne”, o którym „komuś czy czemuś” wiadomo, ma charakter meta-

${ }^{129} \mathrm{D}$ ą b r o w s k i, Trzy utraty. I trzy pożyczki, s. 73.

${ }^{130} \mathrm{Na}$ tę ,zaskakującą, metafizyczną końcówkę” tomu zwrócił uwagę R. Matus ze w ski (Julii Hartwig dowody na istnienie. „Twórczość” 2005, nr 8, s. 100): „Tylko ten, kto - jak autor tych uwag - prześledził uważnie cały tom tych wspaniałych i zadziwiających swą różnorodnością poetyckich medytacji - odczuje metafizyczny dreszcz tego Dowodu na istnienie, kiedy »nie ma już nic, / a miejsca straciły swoje miejsce«. Tylko ten uchwyci sens apologii jedynego, co pozostaje i co mieści się w - z pozoru tylko paradoksalnej - konstatacji: »zostaje niewyobrażalne«. W taki właśnie sposób od najbardziej narracyjnego konkretu wspomnień i związanych z nimi refleksji przebiega droga autorki tomu Bez pożegnania - do jego metafizycznej końcówki”. 
fizyczny, nie oznacza wszak od razu rangi absolutu. Hartwig zdaje sobie sprawę, że o tym, czym jest druga strona bytu, nie sposób wyrokować.

Epifanie nie są pozbawione zupełnie swego tradycyjnego wymiaru oraz konotacji religijnych, przedstawiając metafizyczną tęsknotę za istnieniem sankcji najwyższej. Afirmacja bytu łączy się przecież niejednokrotnie z wdzięcznością dla Stwórcy (To wszystko nie zostało stworzone dla ciebie, WA 21) lub ze wskazaniem na ponadludzkie uzasadnienie świata, jak w utworze Pożegnania, przywitania, podziękowania z tomu Bez pożegnania ${ }^{131}$, gdzie tajemnica bytu odsłania się w drodze wątpienia i podnoszenia się wiary.

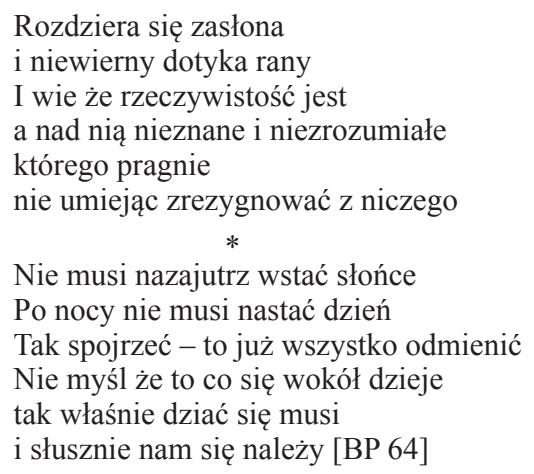

„Rozdarta zasłona” - symbol o proweniencji biblijnej - objawia fakt obiektywnego istnienia świata, którego doświadczenie, ,że jest”, staje się tym samym doświadczeniem najważniejszym. „Nieznane i niezrozumiałe” stanowi to, co warunkuje samo trwanie rzeczywistości, co ją uobecnia. Dualizm ludzkiej egzystencji - umiłowanie świata i tęsknota metafizyczna okazują się nierozdzielne.

Doświadczenie istnienia jest metafizyczne w tym właśnie, że nie jest w stanie wyczerpać się w samym sobie, lecz musi przekraczać, to znaczy transcendować siebie, ku czemuś, co jest inne, a równocześnie uzależniające od siebie nasze własne istnienie. Uzależniające objawia się jako mo c wobec uzależnionego, jako pierwotne wobec pochodnego, jako Absolut wobec przygodności ${ }^{132}$.

U kresu drogi poetki dojrzałej pojawia się zatem pragnienie pewności, wywiedzione także z wiary. Przedmiotem rozważań staje się to, co widzialne, co dane zmysłom w świetle dnia i nocy. Hartwig zatrzymuje się u progu Tajemnicy i nie-

${ }^{131} \mathrm{~N}$ y c z (Literatura jako trop rzeczywistości, s. 132) pisze: „objawienia rejestrowane przez literaturę nowoczesną ewokują poczucie niepowtarzalnej wartości istnienia świata zwykłego i przygodnego; indywidualnych, stających się i przemijających »istnień poszczególnych«, wypełniających świat codziennego doświadczenia. Krótko mówiąc, nowoczesne epifanie są objawieniami - raczej świeckimi niż boskimi-tego, c o ni e be z pośrednio widoczne (a nie tego, co samo wprost się ukazuje), p os zc ze gó ln e (nie tego, co ogólne i uniwersalne), przygodne (nie tego, co esencjalne czy konieczne), mo mentalne (nie tego, co wieczne i niezmienne) oraz u cieleśn i o ne, realnie istniejąc e (a nie tego, co idealne i czysto duchowe)". Badacz zrezygnował z religijno-metafizycznego rozumienia epifanii, koncentrując się na jej wymiarze literacko-estetycznym. Stwierdza, iż „ograniczenie się do wymiaru »ateologicznego«, "pre« czy "parareligijnego« pozwala jednak zidentyfikować ważne wspólne cechy poetologiczno-estetyczne" i jednocześnie nie przekreśla sygnalizowania nowoczesnego typu literackiego dyskursu religijnego ,zakładającego radykalną niewspółmierność »ludzkiej«i »pozaludzkiej«strony rzeczywistości” (s. 7).

${ }^{132} \mathrm{~S}$ tró ż e w s k i, op. cit., s. 129. 
poznawalnego, nie roszcząc sobie prawa do poetyckiej ezoteryki wyrażanej w języku spekulacji, wie bowiem, że ,pytanie jest zarazem wyznaniem wiary / dostępnym każdemu kto pojmie pytanie" (Być blisko, J 34). Późna twórczość Hartwig obfituje w wiersze, które można by nazwać religijnymi czy poświęconymi wierze (Alleluja, Nie wie, Stowo, Robi się coraz później, J 30-32, 53). W poetyckiej refleksji nad wolą człowieczą i Boską, w utworze Getsemane (J 28) agonia Chrystusa w biblijnym Ogrodzie Oliwnym jest osnową dramatycznych, pełnych wątpienia rozważań, wydobywających tragizm męki Jezusa. Syn Boży staje się tu także reprezentantem woli ludzkiej, gdy w przeczuciu swego losu wzywa: ,»Abba Ojcze / Oddal ten kielich ode mnie«" (J 28).

\author{
Gdy mowa między dwoma \\ gdzie miejsce trzeciego? \\ Nie godzi się by ojciec nie pocieszył syna \\ Lecz co wiemy o prawach \\ i ofiarach spełnianych od stuleci? [Getsemane, J 28]
}

W pytaniu tym Hartwig zawarła dążenie do poznania Boskiego planu transcendentnego, ,niedostępnego dla uproszczonych schematów filozofii i nawet samej teologii, a jednak posiadającego jakiś swój sens, jakąś wyższą i najwyższą racjonalność, którą można rozpoznać tylko dzięki objawieniu, na drodze kontemplacji”"133. Leszek Szaruga konstatuje: „Jest w tych wierszach błysk światła odmiennego zarówno od oświecenia rozumu, jak od religijnego objawienia: olśnienie, momentalne, niepochwytne rozpoznanie" 134 . Oto obraz epifanii zamykający ten utwór:

Przecięła niebo nagła błyskawica

rozerwała się ciemność

Byśmy zobaczyli [Getsemane, J 29]

„A oto zasłona przybytku rozdarła się na dwoje z góry na dół” - czytamy w Ewangelii św. Mateusza $(27,51)$. Rozdarta zasłona w religii chrześcijańskiej symbolizuje otwarcie drogi do Ojca dla wszystkich, którzy przyjmą duchowy sens płynący z męki i śmierci Jezusa. Odkrycie istoty zła i cierpienia, ,,praw spełnianych od stuleci" niedostępne pozostaje ludzkiemu poznaniu, poza zasięgiem człowieczej mocy jest także pośredniczenie między Bogiem a Jezusowymi słowami z Ewangelii św. Marka: „Boże mój, Boże mój, czemuś mnie opuścił” $(15,34)$. Tajemnicy nie da się odkryć w sposób racjonalny, przychodzi ona jako moment olśnienia, wskazując na epifaniczny charakter objawienia wyższego zamysłu. Znamienne dla Hartwig jest zatrzymywanie się na granicy „niepochwytności” ${ }^{135}$, dotykanie niewyrażalnego, świadomość, że świat „ma podszewkę”.

Można zatem wyróżnić u autorki Czułości dwa sposoby patrzenia na rzeczywistość. Jądrem pierwszego jest poszukiwanie owego esencjalnego wymiaru ist-

${ }^{133}$ G. R a v a s i, Jak dlugo, Panie? Wędrówka przez tajemnicę cierpienia i zła. Przeł. K. S topa. Kielce 2004, s. 13.

${ }^{134}$ L. S z a r u g a, Pytania Julii Hartwig (notatki krytyczne). „Kwartalnik Artystyczny. Kujawy i Pomorze" 2009, nr 2, s. 131.

${ }^{135}$ Zob. na ten temat M. S t a l a, Krucha nieśmiertelność. W: Druga strona, s. 74-75: „Najpiękniejsze miejsca poezji Julii Hartwig onieśmielają, wymykają się pojęciowym porządkom. [...] trzeba się poddać rytmowi fraz, sugestywności obrazów, sile emocji. Interpretacja niewiele tu wyjaśni, wiele może zniszczyć". 
nienia, ukrytego sensu, drugi opiera się na poczuciu nieograniczonego bogactwa tego istnienia, na wszechstronnej chłonności wobec migotliwego świata, który objawia się w formie „stworu, fragmentu, zawieruchy, wspaniałego obłędu jasnego umysłu" (Pod ta wyspq..., W 17). Hartwig ukazuje się jako poetka paradoksów i graniczności, klasyk ze swobodą posługujący się mową nocy, zamkniętą w precyzyjnej poetyce zdania. Sfery irracjonalna, przeczuciowa, podświadoma współgrają z poezją rozumu i inteligencji, decydując o często dramatycznym, ale jakże płodnym napięciu tej twórczości. Świat poetycki spaja tu realne z onirycznym, wykracza poza pojmowalne i jednoznaczne. Stąd wiersze, osadzone w widzialnym konkrecie, zapełniają się zjawami, serafinami i duchami zmarłych. Rozmach tego pisarstwa zadziwia. Odbywa się w nim ciągły spór o model egzystencji, trwa próba ogarnięcia świata, który ,jest”. Zachłanność istnienia jako siła rozwojowa twórczości Hartwig sprzęga się z wyważoną drogą środka, zarówno w pojmowaniu sztuki, jak i w szeregu zagadnień egzystencjalnych. Między chaosem a ładem, na styku sprzeczności, między fragmentem a wierszem - otwiera się szansa oddania ciągłej zmienności egzystencji i świata, zmienności, której nie da się zamknąć w zwartej formule.

\section{Abstract}

MARTA FLAKOWICZ-SZCZYRBA

(University of Varmia and Masuria, Olsztyn)

\section{JULIA HARWIG'S POETRY TOWARDS EXISTENCE AND METAPHYSICS}

The speaking subject in Julia Hartwig's poetry oscillates between a burden of existential exile, catastrophic consciousness, and a need of regaining order and sense of existence, as well as reveals metaphysical longing inherent in a man. The author pays attention to the act of "seeing the good" fundamental for Hartwig's poetic epiphanies. The analysis of the category in question is supported with Ryszard Nycz's and Charles Taylor's views. The epiphany in Hartwig's early poems refers to a dream vision, whilst later it emerges in intensive experience of the reality. Being a subjective experience, a moment of revelation, it is born in the act of internalizing the visual. Admiration is derived from the power of sight and equalled to faith as regards the power of revelation of existence in full blossom. The epiphanies many a time point at superhuman sanction of the world and at a feeling of unspeakable richness of existence. 